INVESTIGATING FLOOD IMPACTS AND ADAPTATION MEASURES FOR THE CITY OF TORONTO

\author{
By \\ Megan Ketchabaw \\ B.A. (Hons.), Wilfrid Laurier University, 2012

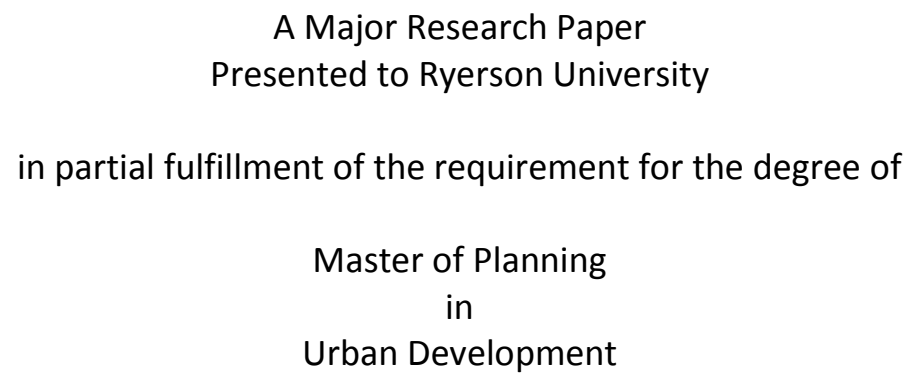

Toronto, Ontario, Canada, 2014

CMegan Ketchabaw 2014 
I hereby declare that I am the sole author of this major research paper. This is a true copy of the major research paper, including any required final revisions, as accepted by my examiners.

I authorize Ryerson University to lend this major research paper to other institutions or individuals for the purpose of scholarly research.

I further authorize Ryerson University to reproduce this major research paper by photocopying or by other means, in total or in part, at the request of other institutions or individuals for the purpose of scholarly research.

I understand that my major research paper may be made electronically available to the public. 


\title{
INVESTIGATING FLOOD IMPACTS AND ADAPTATION MEASURES FOR THE CITY OF TORONTO
}

(C) Megan Ketchabaw, 2014

\author{
Master of Planning \\ In \\ Urban Development \\ Ryerson University
}

\begin{abstract}
The City of Toronto has had a long history with, and relationship to flooding. The most severe flooding on record in Ontario occurred in October of 1954 when Hurricane Hazel struck the City of Toronto and surrounding areas. This storm event initiated and helped to shape flood risk management and policy planning in the region. Overtime the city's approach to stormwater and wet weather flows evolved from flood control to management. The current approach is guided by the city's Wet Weather Flow Management Master Plan, an overarching plan to manage water flows in the city. With the expected impacts of climate change further increasing the need to effectively manage water in Toronto, it is important to look at and understand the measures the city is taking to plan for and relieve flood risk into the future. From analysis of existing literature and best practices in urban flood risk management, recommendations for improvements to the current master plan, policies, and management are made.
\end{abstract}

Key words: flood risk management, wet weather flows, climate change, resilience, Toronto 
Foremost, I would like to express my sincere gratitude to my supervisor Prof. Nina-Marie Lister for her advice, immense knowledge, and support. Her guidance helped me to focus my ideas and effectively research and write this MRP.

I would also like to thank my second reader Prof. Elise Shelley for taking the time to review and provide insightful feedback on my paper.

Finally, I would like to thank my family for their support and encouragement through the entire process of researching and writing this MRP, and in achieving the Master of Planning in Urban Development degree. 
Table of Content

1.0 Introduction

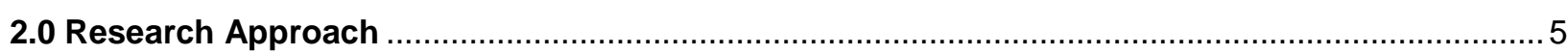

3.0 Setting the Stage: Background and Literature Review ...................................................... 7

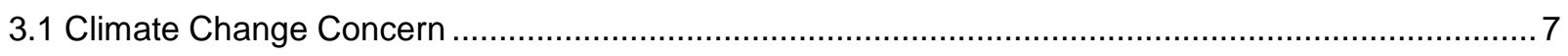

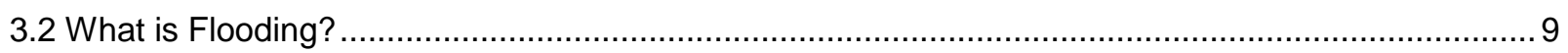

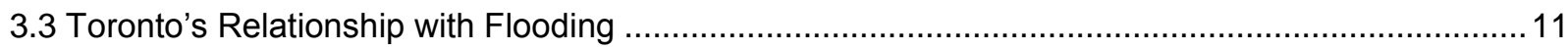

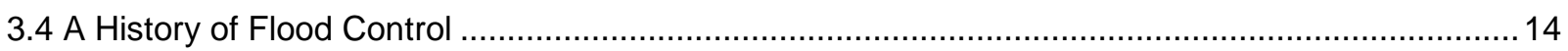

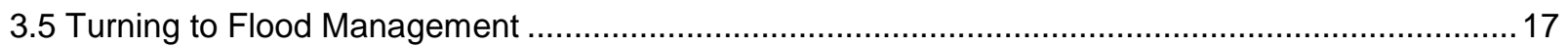

3.6 The Importance of Conservation Authorities: Creation of the TRCA ….......................................21

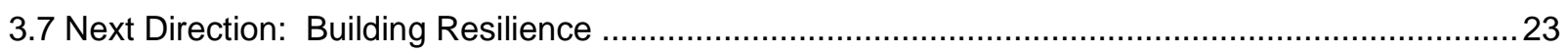

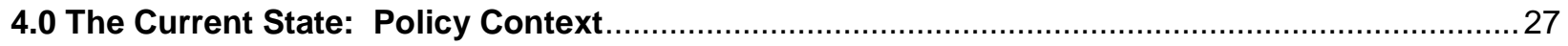

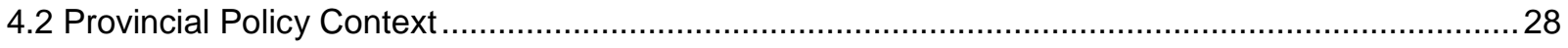

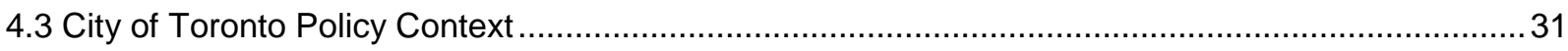

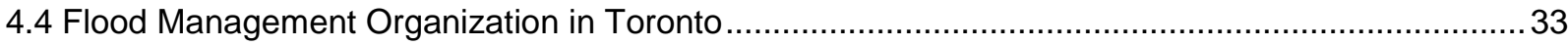

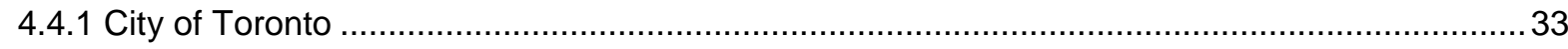

4.4.2 The Toronto and Region Conservation Authority ............................................................... 34

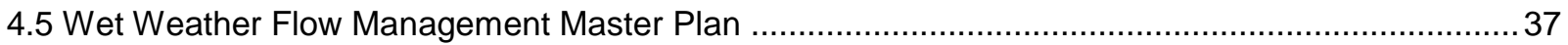

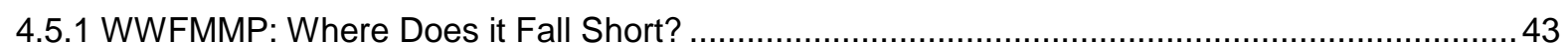

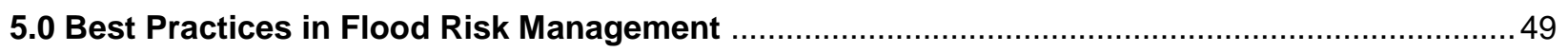

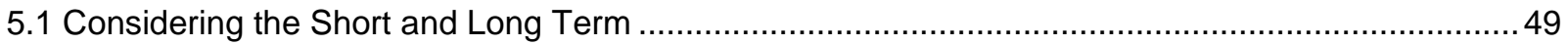

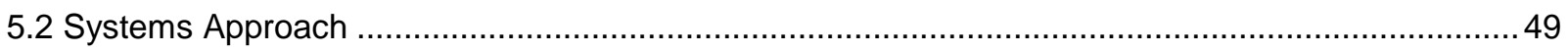

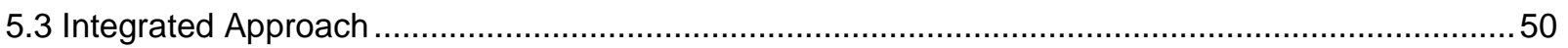

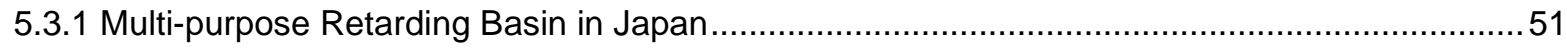

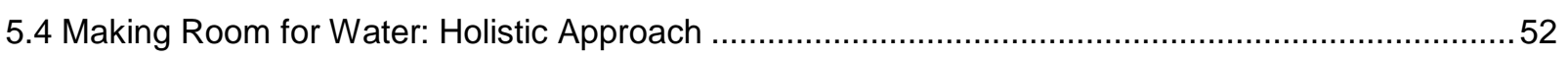

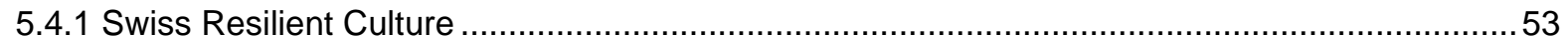

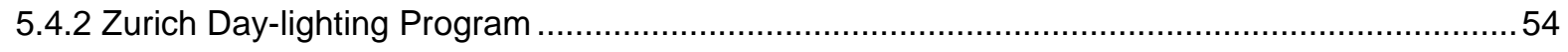

5.4.3 The Netherlands: Making Space for the River program ...................................................5 54

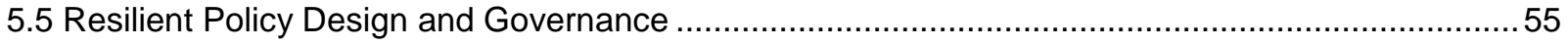

5.5.1 Rebuild by Design and Water Management in New York City ..............................................59

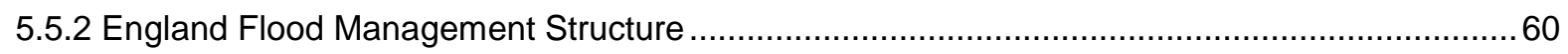

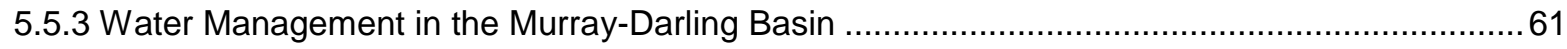

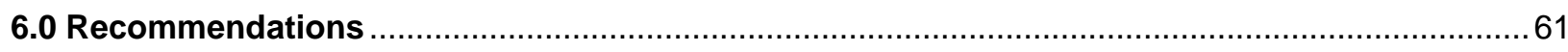

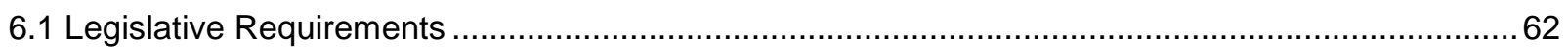

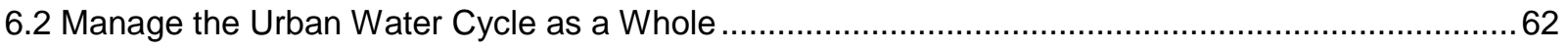

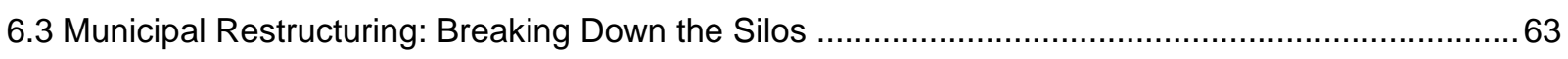

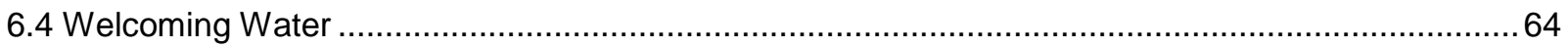

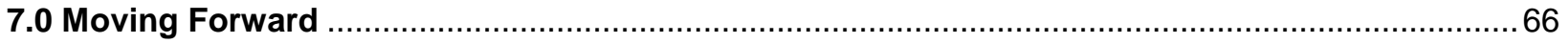

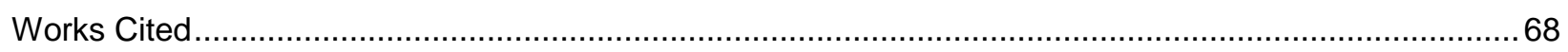




\section{List of Tables and Figures}

\section{Tables}

Table 1: Types of Floods Toronto is most Susceptible to

Table 2: Components of Flood Management and Forecasting

Table 3: TRCA Flood Management Service Programs

Table 4: Four Crucial Aspects of Resilience

Table 5: PPS Update Related to Water Management from 2005-2014

Table 6: Principles of Flood Risk Management

Table 7: TRCA Flood Message

Table 8: Wet Weather Flow Management Policy Objectives

\section{Figures}

Figure 1: July 8, 2012, Flooding Toronto

Figure 2: Comparing Toronto Storm Events

Figure 3: Projected Rain and Snowfall in Toronto

Figure 4: Steep Well Defined Don Valley Toronto

Figure 5: Finch Avenue, Toronto, Flooding August 19, 2005

Figure 1: Hurricane Hazel Flooding

Figure 2: City of Toronto Flood Vulnerable Areas

Figure 3: TRCA Flood Control Structures

Figure 4: TRCA Jurisdiction and Participating Municipalities

Figure 5: Understanding Resilience: The Four Ecosystem Functions $(r, K, \Omega$, and $\alpha$ ) Organized into an Adaptive Cycle

Figure 6: WWFMMP Study Areas

Figure 7: WWFMMP Original Implementation Schedule

Figure 8: WWFMMP Project Locations

Figure 9: Etobicoke Vegetative Rafts

Figure 10: Multipurpose Retarding Basin Japan

Figure 11: The three pillars of decision making for sustainable development

Figure 12: Designing with Nature for the Future of the Mid-Atlantic Coast 


\subsection{Introduction}

Ontario is a land of lakes. Lakes and other waterbodies alike are a part of our lives, so much so that over the years we have taken them for granted, and have been very careless with their well-being (McLean, 2004). Toronto, named the "accidental" city by Robert Fulford, is where it is, because of its lake location and its water connection. The combination of a sheltered harbour and the shortest inland route to the upper Great Lakes led to the establishment of the city (McLean, 2004). A series of events or unplanned "accidents" structurally transformed Toronto, creating its ravines, monuments, neighbourhoods, and underground networks (Fulford, 1995). One of those events - Hurricane Hazel helped to develop and shape the way that water was first controlled and then managed in the City of Toronto.

The City of Toronto has had a long history with, and relationship to flooding. This was made very apparent in the summer of 2013 , with two extreme flood events having debilitating effects on the City. Throughout the past decade there have been an increasing number of these weather events along with their devastating impacts on urban areas across the country. Most provinces in Canada have experienced significant flooding with related economic losses, the most recent being in the Cities of Calgary, Halifax and Winnipeg (Martin-Downs, 2013). Internationally the issue of flooding is large and widespread, with major flooding from Tropical Storm Sandy, October 2012, hitting New York and New Jersey, and the 2011 typhoon and monsoon season in the Philippines causing record flood events as examples (Martin-Downs, 2013; CNN, 2011). Could Toronto be the next Calgary, or Manhattan? The City of Toronto could also be part of this list in the future if the necessary measures in flood defense are not taken.

The most notable recent severe weather system hit Toronto and the Greater Toronto Area (GTA) on Monday, July 8, 2013, and produced a series of severe thunder storms that released large 
quantities of precipitation in a very short period of time.
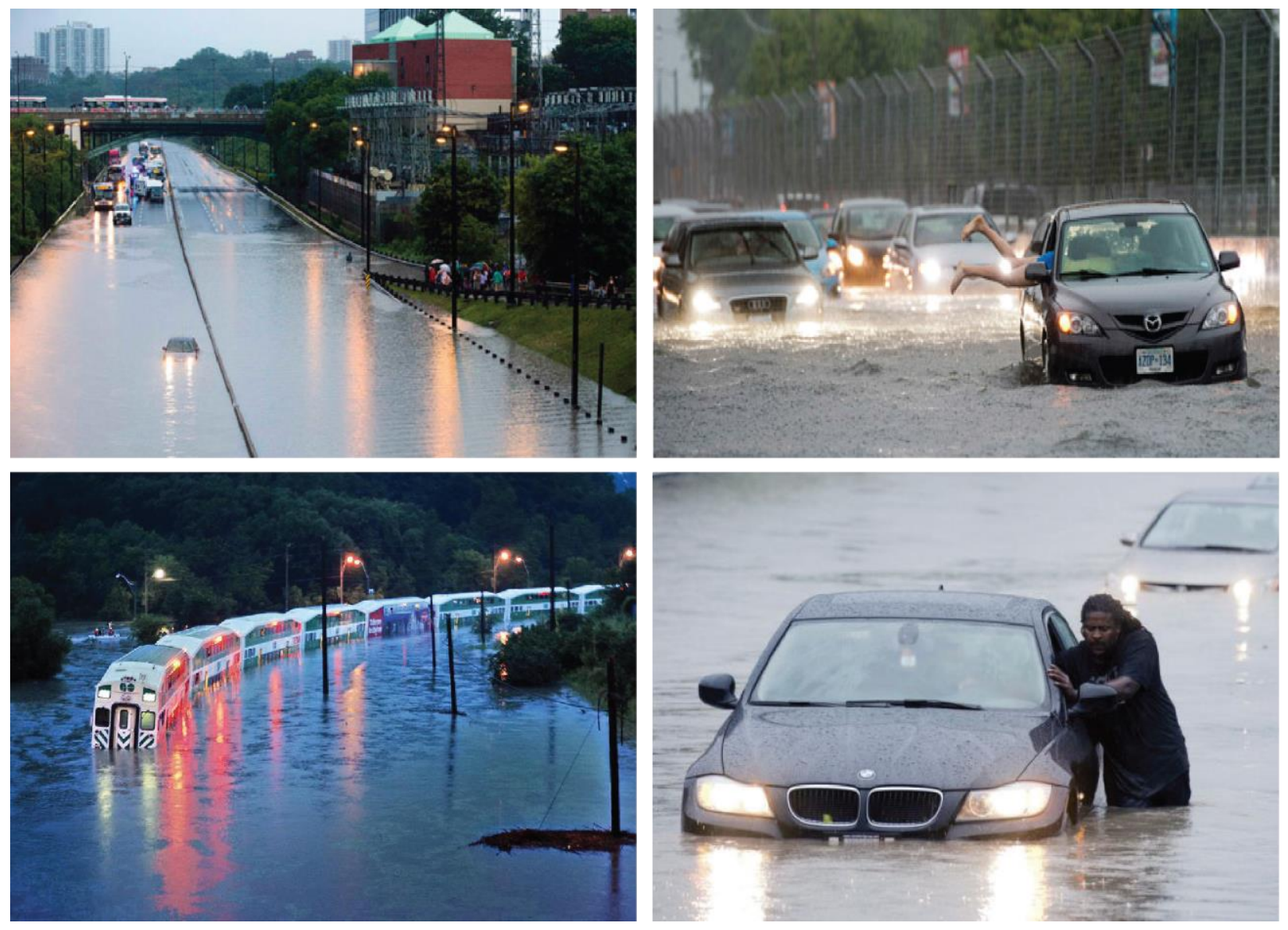

Figure 13: July 8, 2012, Flooding Toronto (Sources: Blinch, 2013; Gunn, 2013; Neutel, 2013; The Canadian Press, 2013)

Much of the media reporting on the storm suggested that this event was "bigger than Hazel" and that it was the largest volume of rainfall the city had ever seen from one weather system (Martin-Downs, 2013). However, the Hurricane Hazel event as a whole produced much more rain than the July $8^{\text {th }}$ event and the period of rain was much longer (Martin-Downs, 2013). This storm event primarily produced issues associated with urban flooding by overwhelming the city's stormwater sewer systems and flooding low lying areas on roadways and in underpasses. Riverine flooding and extremely high water levels occurred on several watercourses within the Toronto and Region Conservation Authority's (TRCA) jurisdiction, causing portions of roadways to be flooded (Martin-Downs, 2013). Flooding is inevitable, 
and it will continue to happen in Toronto.
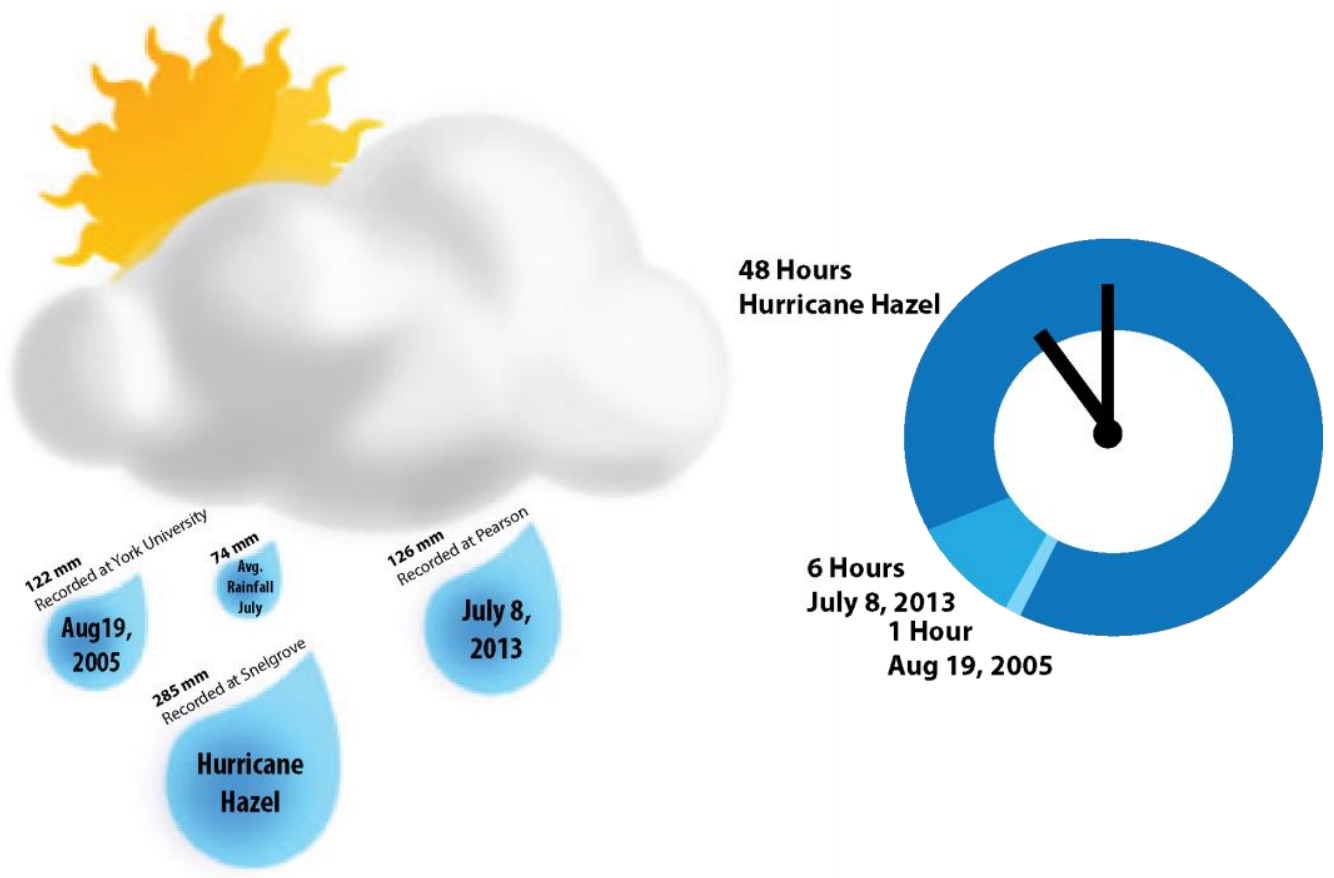

Figure 14: Comparing Toronto Storm Events (Data Source: TRCA, 2013)

Toronto's waterfront, both lakefront and riverfronts are home to a variety of land uses that include but are not limited to: residential and commercial uses, parks and natural areas, historic sites, and abandoned industrial lands. These bodies of water give life to the city and play an important role in flood defense, managing flood risk, and protecting the city from the impacts of climate change and possible lake level rise. Today, many cities around the world are increasingly reimaging and reacquainting themselves with the water's edge (Lister, 2009). The city's watercourses are among its most important resources, and given this, it is important for Toronto to recognize that water has, and always will continue to shape the city's land. Water should be thought of as the "connective tissue" between city neighbourhoods and something that brings people together and to the waterfront, not away from it (Burden, 2011). Urban waterfronts, Toronto's included, must welcome and embrace the uncertainty associated with the forces that continually shape them. This approach will allow for a 
deeper understanding of, connection to, and more resilient relationship with our waterfront (Lister, 2009). A force with a particularly strong impact and uncertainty is climate change.

Climate change is increasingly understood to have a significant impact on flood risk, and new and intensified phase of urbanization in Toronto coupled with spatial expansion is implicated in, and compounds flood risk (Government of Canada, 2012). It is vital to link urban flood risk management to urban planning and management, including land administration, land use planning, housing provision, urban infrastructure delivery and basic service provision. Going forward it is important for planners to consider that rapid expansion of urban built up areas provides the prospect of new development locations that can incorporate flood management techniques from the outset (Godschalk, 2003). Similarly, planners must also consider a recovery plan as an opportunity for reconstructing safer and stronger communities which have the capacity to better withstand future flooding. It is also important to recognize flood aware planning as the most promising strategy for successful flood risk management in the long run, to help build a more resilient city (Jha et al., 2005). A resilient city responds to change or shocks and stresses in a way that it is able to retain its basic functions while realizing a new state of normal. As such, the aim of this paper is to understand some of the current measures and policies the City of Toronto is using to alleviate the impact of flooding across the city in the face of climate change, and seeks to make recommendations for improvements to be made to the existing organization and management structure. 


\subsection{Research Approach}

The City of Toronto has experienced flooding throughout its history which has overtime led to a change in the city's approach to water management. The current approach is guided by the city's Wet Weather Flow Management Master Plan (WWFMMP), an overarching plan to manage water flows in the city. With the expected impacts of climate change further increasing the need to effectively manage water in Toronto, it is important to look at and understand the measures the city is taking to plan for, and relieve flood risk moving into the future. From this analysis, recommendations for improvements to the current master plan, policies, and management will be made. A central research question was developed to speak to the aim of this paper and will be addressed:

- What measures are currently being taken by the City of Toronto to mitigate adverse impacts of flooding?

Further sub-questions that will also need to be addressed within this research include:

- Has the City of Toronto developed resilient policy related to flood risk?

- Does Toronto take into account that flood risk might change due to climate change?

- Is new urbanization in Toronto respecting future flood risks?

To understand Toronto's current flood management practices it is first essential to review the city's history with and relationship to flooding, and how that relationship has changed over time. The process of making recommendations to improve the current organization and management of flooding in Toronto will be informed by a background and literature review section that emphasizes the evolution of flood management in the city; an assessment of existing provincial and municipal policy contexts paying specific attention to the WWFMMP; and an exploration of best practices in urban flood risk management approaches. The research approach of the paper is grounded in an analysis of secondary research and a broad policy scan, and uses sources such as books, journal articles and city planning documents. The approach taken for this research paper is both exploratory and descriptive, with the purpose of examining and "painting a picture" of the issue of flooding in Toronto at a moment in time 
(Neuman, 2011). This paper draws upon and synthesizes the major themes and issues related to urban flood management in the City of Toronto. 


\subsection{Setting the Stage: Background and Literature Review}

\subsection{Climate Change Concern}

An increase in extreme precipitation is expected by many flood experts to increase flood risk. A global analysis conducted, found initial evidence that the number of severe floods (those exceeding 100 year levels) in large river basins has increased over the twentieth century and is expected to continue to increase (Milley et al., 2002). However, there has been some disagreement between researchers who run climate models and those who look at the historical record of flood stages. A concern or conflict arises because flood stages are related to precipitation in a complex way and it is difficult to detangle the competing forces of climate change, land use, dam operation, levee construction, and other flood control measures (Kousky et al. 2013). It becomes even more difficult because flood events depend not only on precipitation but also on antecedent soil moisture and changes in frozen ground cover, both of which may be influenced by climate change (Hirsh, 2011). All researchers have however concluded that climate change impacts have yet to be seen in full, thus creating a disconnect between historical record and future projections (Kousky et al., 2013).

Historically, the GTA has received weather that could potentially lead to flooding in four different ways: 1) spring melting of the snowpack, 2) rainfall on snow events during the winter season, 3) severe thunderstorm activity with short localized intense rain bursts, or 4) large precipitation volumes over a long period of time brought on by hurricane activity (Martin-Downs, 2013). It is important to note that Toronto does not have the same level of climate risk as some other cities, such as Halifax or New York, cities that are directly exposed to hurricane activity.

To better understand Toronto's climate and how it might change, Toronto's Future Weather and Climate Divers Study was conducted in 2012. The Study was concieved to help interpret the meaning of global and regional climate scale model prodictions for the much smaller geographic area of the City of Toronto. It was found that without the Great Lakes, Toronto would have an "extreme continential 
climate", however, Toronto has a "contenential climate", one that is greatly affected by the Great Lakes and other physiogeographical features (SENES, 2012). The study predicts that climate change will continue to create different weather patterns across Toronto in the feature. While some changes might be positive, the negative changes are what needs to be managed and planned for. The study predicts that a similar number of storms per year are projected and a fewer number of "heavy" storms ( $>25 \mathrm{~mm} /$ day) are expected (SENES, 2012). However, a small number of those storms are expected to produce "very intense" storms that generate much greater amounts of rainfall in short periods than previously seen, with clear impacts on city infrastructure (culvert and drainage management) and an increased potential for flooding (SENES, 2012).
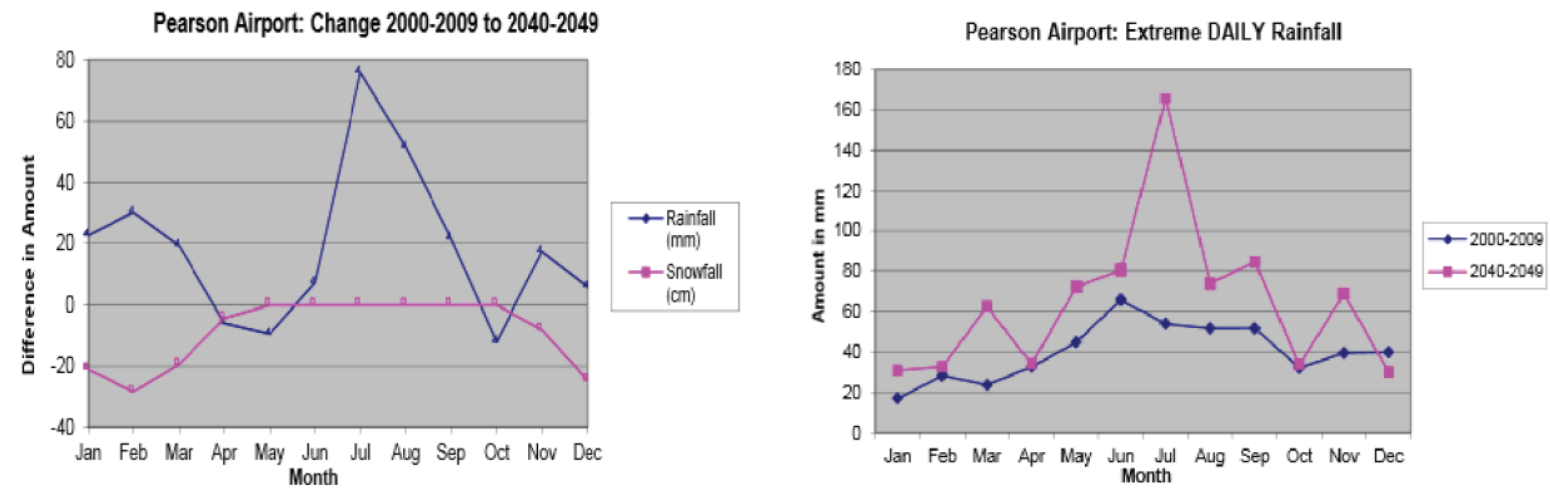

Figure 15: Projected Rain and Snowfall in Toronto (Source: SENES, 2012)

The City of Toronto developed and approved its Climate Change Action Plan in 2007, which was followed by the city's Climate Adaptation Strategy, Ahead of the Storm: Preparing Toronto for Climate Change in 2008. This document outlines a number of actions that seek to improve the city's resilience to climate change and extreme weather events. Climate change adaptation can be defined as "initiatives and measures taken to reduce the vulnerability of natural and human systems to actual or expected climate change effects" (City of Toronto, 2008, p. 8). Some examples of climate change adaptive actions include raising river or coastal dikes, and substituting more temperature-shock resistant plants for sensitive ones (City of Toronto, 2013). This background and literature review is meant to provide a 
detailed account of the history of the City of Toronto's relationship with, and approach to flooding in the region.

\subsection{What is Flooding?}

Floods are a common and widespread natural hazard across Canada (TRCA, 2012). Flooding in Ontario is known to be a common occurrence. It is defined as "the overflowing of the normal confines of a stream or other body of water caused by natural phenomena (e.g., weather) that threatens the safety, welfare of people, and/or damage to public and/or private property" (Ministry of Natural Resources (MNR), 2008).

Floods are natural phenomena and cannot totally be abolished no matter what remedial action is taken in the watershed. As long as people continue to live in the flood plains, there will be flood victims Report on the Royal Commission Inquiry into the Grand River Flood 1974 - Commissioner: His Honour Judge W.W. Leach (MNR, 2008, p. 7)

In Ontario, policies related to flooding were established after the 1954 Hurricane Hazel storm which has greatly restricted the amount of allowable development within floodplains. However, many historical structures still exist and are at risk (TRCA, 2012).

Toronto is most susceptible to riverine, flash, urban, and dam break flooding (TRCA, 2012). The city's large watersheds greatly add to its susceptibility to flooding. Other causes of flooding include locally intense

thunderstorms, rain or snowmelt, and ice jams. Coastal flooding from Lake Ontario is less common within the City of Toronto, however it is a potential flood type as well.

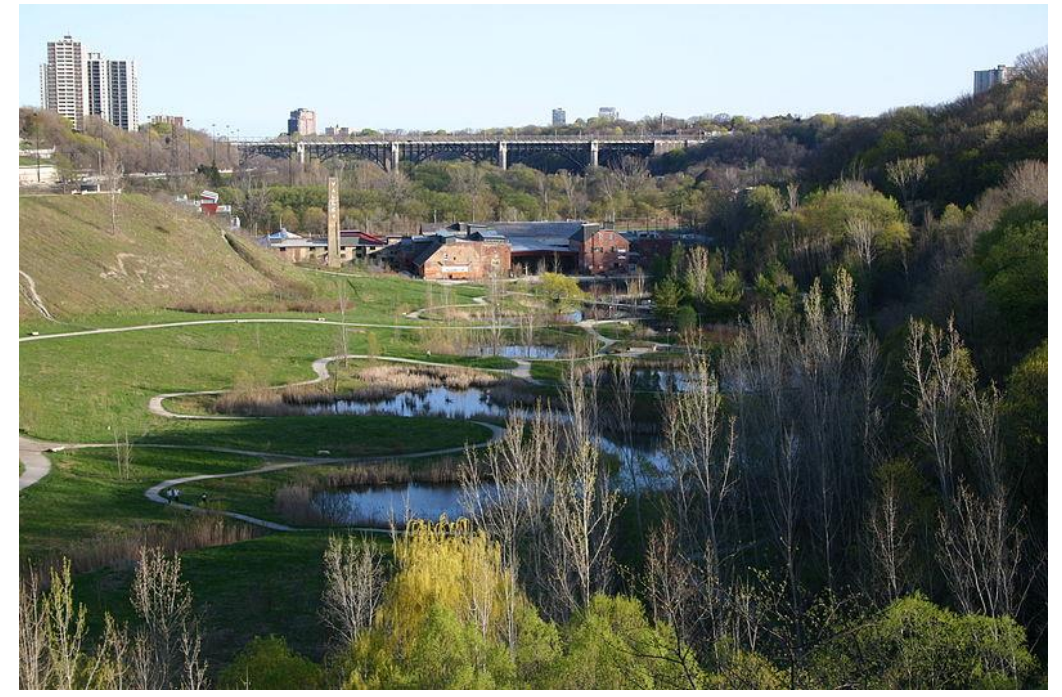

Figure 16: Steep Well Defined Don Valley Toronto (Source: Wang, 2011) 
Water that falls on the ground as precipitation needs to go somewhere. Most of it finds its' way into the many rivers, creeks and streams of the city. Toronto's valley systems are steep and well defined (shown in the image above) and easily convey water quickly to the Lake (TRCA, 2012). This means that water levels do not remain high for prolonged periods of time during normal routine storms. Whereas areas in northern Ontario or parts of Manitoba experience flooding for weeks to months, Toronto's severe weather events usually cause flooding for hours to days (TRCA, 2012).

Table 1: Types of Floods Toronto is Most Susceptible to

\begin{tabular}{|l|l|}
\hline Type & $\begin{array}{l}\text { Description } \\
\text { Riverine }\end{array}$ \\
$\begin{array}{l}\text { A riverine flood is defined as a condition where water levels in a watercourse exceed the } \\
\text { channel bank elevation. This type of flooding typically results from large-scale weather } \\
\text { systems generating prolonged rainfall }\end{array}$ \\
\hline $\begin{array}{l}\text { Flash floods can result in raging waters in matter of minutes. Flash floods, which are } \\
\text { characterized by rapid on-set and high velocity waters, carry large amounts of debris. } \\
\text { Several factors contribute to flash flooding. The two key elements are rainfall intensity and } \\
\text { duration. }\end{array}$ \\
$\begin{array}{l}\text { As land is converted from fields or woodlands to roads and parking lots, it loses its ability } \\
\text { to absorb rainfall. Urbanization increases runoff } 2 \text { to } 6 \text { times over what would occur on } \\
\text { natural terrain. During periods of urban flooding, streets can become swift moving rivers, } \\
\text { while basements fill with water. }\end{array}$ \\
\hline Dam Break & $\begin{array}{l}\text { Dam break flooding is the failure of flood control structures that are constructed to assist } \\
\text { in attenuating flood flows. The greatest risk associated with a dam failure often occurs } \\
\text { during "sunny days" when there is not necessarily a major storm even happening, but a } \\
\text { structural failure of the dam occurs. }\end{array}$
\end{tabular}

(TRCA, 2012)

Urban growth and development in the City of Toronto and surrounding areas have, and will continue to put very intense pressures on the ecosystem which result in the alteration of the hydrologic cycle and the natural environment. It has been found that urban development has two major effects on water flows in urban environments; increased stormwater runoff quality and quantity (Marsalek et al., 2004). Increases in impervious area, changes in surface grading and high surface runoff associated with urban development all act to "reduce stormwater infiltration into the ground and increase the volume and peak flow rates of stormwater runoff to receiving waters" (Marsalek et al., 2004, p. 57). What has been termed as "wet weather flow" is defined as "any storm made surge of water - rain or snowmelt", 
and results in combined sewer overflows, storm sewer discharges, and infiltration and inflow into the sanitary sewer system causing treatment plant by-passes all of which contribute to degraded water quality in area watercourses and the waterfront (EPA, 2013; Marsalek et al., 2004, p. 57). The consequences related to this include "increased flooding and erosion, physical destruction of terrestrial and aquatic habitat, reduced stream base flow, postings of recreational beaches, nutrient enrichment, contaminated sediments, stressed aquatic communities and degradation of the overall environment" (Marsalek et al., 2004, p. 57). The floods experienced in the past have heightened the awareness of the destruction that flooding can cause, and the effects it has on society and the environment.

\subsection{Toronto's Relationship with Flooding}

Flooding has been known to be a problem in the Toronto region since the early stages of the city's development. The first written account of a flood in the region was as early as 1797 and records since that indicate that flooding has been a continuous issue (TRCA, 2000). The first severe flood hit the region in 1878. It was accounted that downtown Brampton received five inches of rain which fell in less than seven and a half hours producing severe flooding that caused damages to both stores and homes. Infrastructure such as bridges, mills and dams were washed out, damaged or destroyed (TRCA, 2013). This flood event and others that followed led to a greater understanding of flood potential in the region and started the motion towards flood control in the Greater Toronto Area (GTA) (TRCA, 2000). As the GTA expanded and became more urbanized, the idea and thought of flood control also expanded (TRCA, 2013).

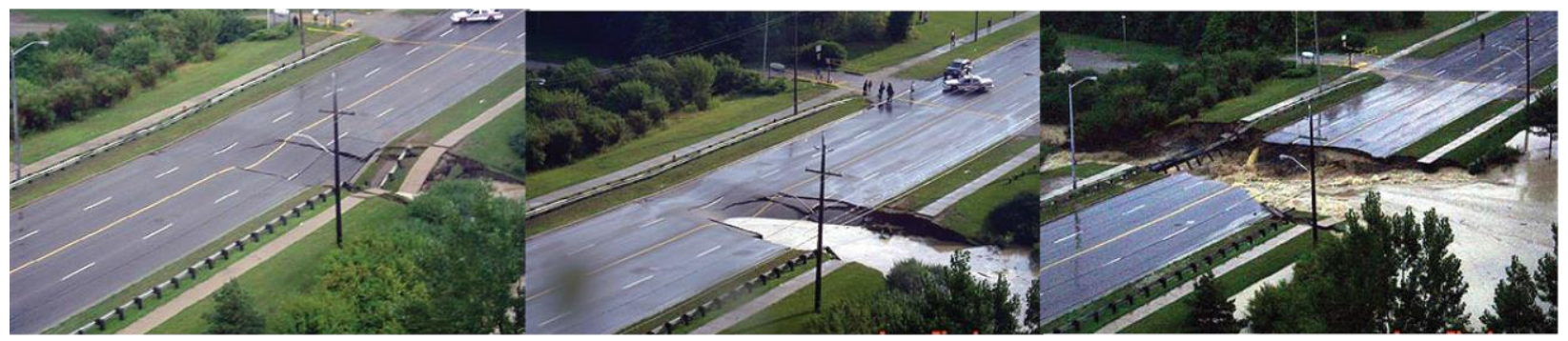

Figure 17: Finch Avenue, Toronto, Flooding August 19, 2005 (Source: www.jane-finch.com) 
According to historical flood data, most flooding in the region has occurred and continues to occur in the spring as a result of snowmelt and ice jams (TRCA, 2000). In the summer months southern Ontario also experiences tropical storms or their remnants on average once every two years (TRCA, 2000). Hurricanes, such as Hurricane Hazel, are tropical storms with winds greater than 64 knots.

Storms of this magnitude usually result in large amounts of precipitation and can act in conjunction with high flows or saturated soils which act to increase the chance of a flood event (TRCA, 2000).

The most severe flooding on record in Ontario in terms of loss of life occurred in October of 1954 when Hurricane Hazel passed over the City of Toronto and surrounding areas. Over two days 210 millimetres of rain fell within a period of 12 hours (TRCA, 2000).

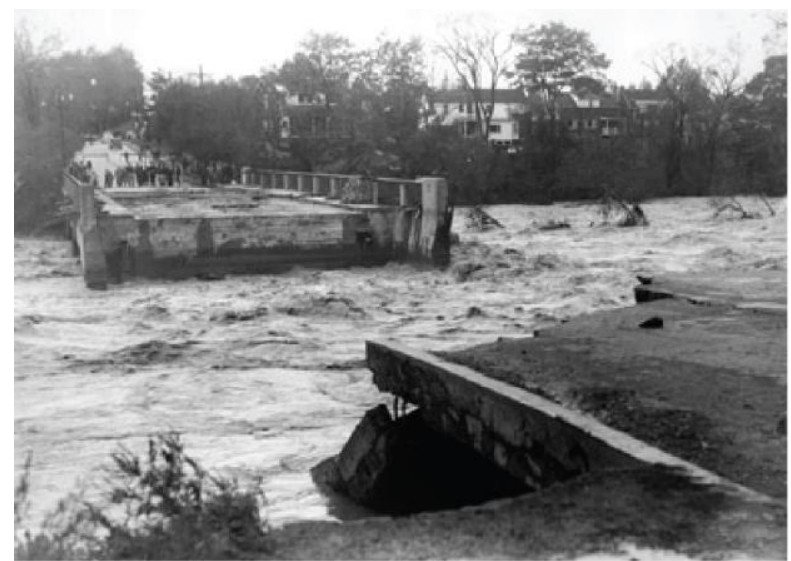

Lawrence Avenue Bridge

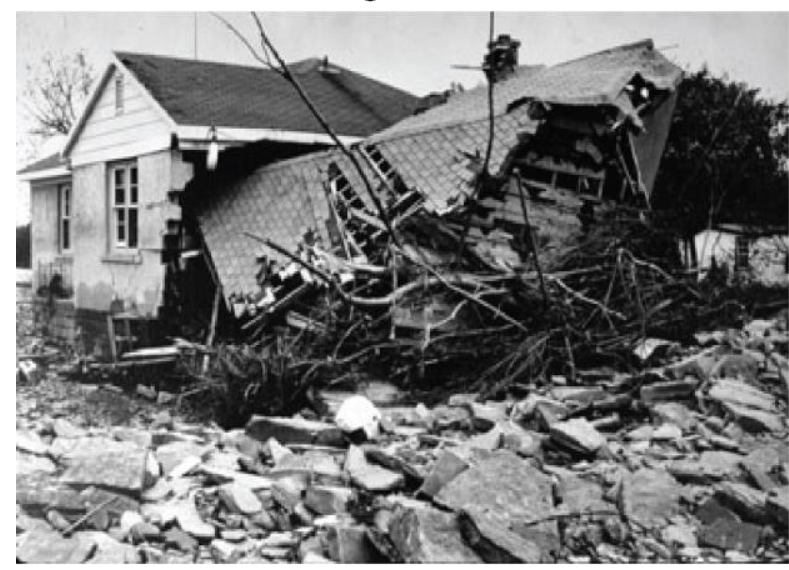

House on Raymore Drive

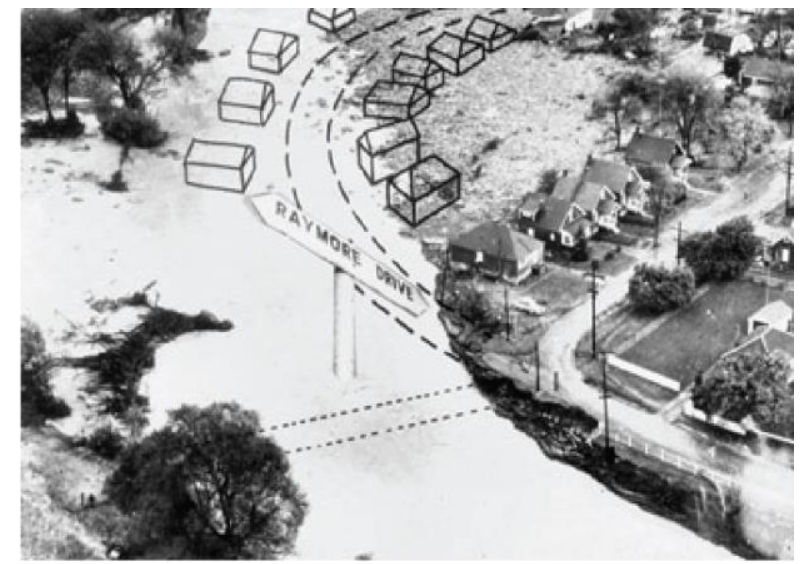

Washed Out Street at Raymore Drive

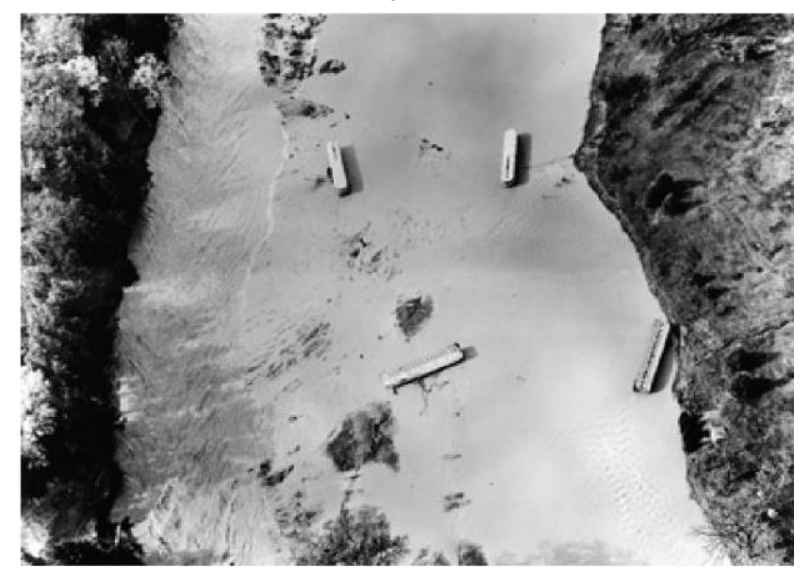

Streetcars Deposited in the Humber River

Figure 18: Hurricane Hazel Flooding (Source: www.hurricane-hazel.ca) 
Flooding was inevitable during this event as previous rainfall saturated the soils preventing infiltration and thereby funneling most of the rain water into the region's watercourses (TRCA, 2000). In total, 81 lives were lost in this disaster and damages were estimated at \$25 million in 1954 which is equivalent to almost $\$ 170$ million in the year 2000 dollars (MNR, 2008). Most of the bridges on the west side of Toronto and many on the Don River were badly damaged or destroyed. Many roads, public utilities, parks, and an entire street of houses in Toronto were also washed out during and after the storm. While the damage and loss of life made Hurricane Hazel such a terrible event, what is surprising is that most of the damage could have been avoided. Toronto knew from past experience the devastating effects of a river in flood, but the city did not take steps to prevent the event. The aftermath of Hazel saw an unprecedented effort of cooperative planning and regeneration for the Toronto area. For a period of almost 30 years after Hazel all levels of government worked together and equitably shared costs for this undertaking. Of all the plans and projects that have shaped the Toronto region through its history, it is unlikely that any have been as far reaching and beneficial (McLean, 2004).

Currently, there are a large number of flood susceptible developments along Ontario's watercourses that were settled prior to the current provincial planning standards. The rainfall event that occurred at the time of Hurricane Hazel has helped to shape flood management practices and policies across Ontario (MNR, 2008). This event has been used as the flood standard to determine the flood hazard in the province. Although policies concerning the flood hazard provide for a level of flood prevention in Toronto, they do not provide for protection from events that exceed the current standards. Flooding can happen at any time of the year and there is an increasing concern that it will increase due to climate change (MNR, 2008). Events such as Hazel should be seen as an event that may be exceeded and should not be viewed as the "worst possible event" (MNR, 2008). It has been noted by the TRCA that areas beyond those determined as flood hazard may also be subject to future flooding. 


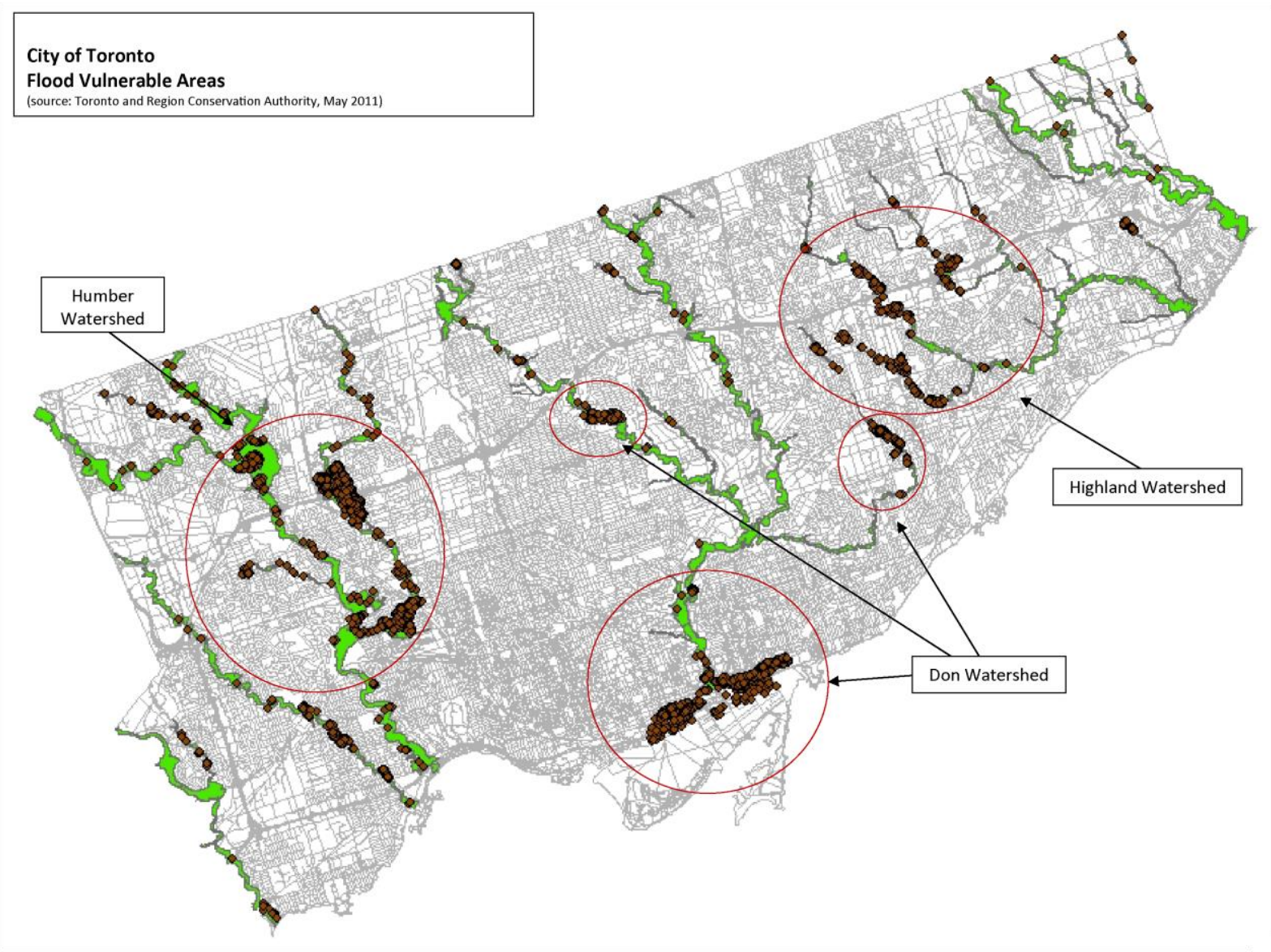

Figure 19: City of Toronto Flood Vulnerable Areas (Source: TRCA, 2011)

\subsection{A History of Flood Control}

Control was the first approach taken towards the management of flood waters in the City of Toronto. This approach was born by a fear of floods and their associated destruction. We as a society have spent years trying to control floods by building structures such as levees, dams, and channels to modify the way rivers flow (Haeuber \& Michener, 1998). Flood control is defined as "all methods used to reduce or prevent the detrimental effects of floods waters, usually through the construction of physical control structures" (Zevenbergen \& Geronius, 2007, p. 2).

In the 1940s development increased in previously unurbanized areas, and the Toronto region continued to grow. The responsibility for managing natural resources historically lay with the province, and at this point in time the scale of erosion and water problems was such that it required a new 
approach. Natural resources including water were becoming commodities which needed to be regulated and controlled as a result (TRCA, 2000). In 1944, a decision was made with the support of a number of Ontario municipal councils to find a new method of water resource conservation in Ontario (TRCA, 2004). A conference was organized in London, Ontario, to discuss the direction for the future of water regulation in the province. From the conference, a conservation branch in the provincial government was created (Richardson, 1974). In 1946, the Conservation Authorities Act was passed as a result of this new branch of government. The fundamental concepts of this new approach were embodied in the Act and include: local initiative, cost sharing, and watershed jurisdiction (TRCA, 2004). From the Act several conservation authorities were established to deal with pressing flood control issues (Richardson, 1974). These conservation authorities mainly dealt with local flooding problems and reforestation within their watersheds. Then in 1957 the existing Conservation Authorities were amalgamated into the Metropolitan Toronto and Region Conservation Authority (MTRCA), which was later renamed the Toronto and Region Conservation Authority (TRCA, 2000).

Hurricane Hazel has been recognized as the jump-start for the TRCA's flood control program. When 210 millimetres of rain fell on October $15^{\text {th }}$ and $16^{\text {th }}$ of 1954 in a twelve hour period, the Ontario Provincial government began to seriously look at methods of flood control and prevention (TRCA, 2013). The Provincial government seeing the importance of flood management amended the Conservation Authorities Act to enable an Authority to acquire lands for recreation and conservation purposes. In 1959 The Plan for Flood Control and Water Conservation was finalized and consisted of three stages (TRCA, 2013). Within this plan 15 large control dams were marked to be built, four major flood control channels, and the initiation of an erosion control program began (TRCA, 2000).

The creation and implementation of the Lands Acquisition Program in 1960 was the initial stage of the plan. The purpose of this program was to transfer to the Authorities the liability of floodplain land from private hands, allowing for the necessary lands to be attained for construction of flood protection 
and prevention works (TRCA, 2013). The second stage involved the creation of flood control works. The intent of this stage was to construct as many physical structures as was necessary to control flooding. Such works consisted of reservoirs, dams, channel improvements, and other infrastructure (TRCA, 2013). The cost of these works, which were designed to control and minimize damage in flood prone areas, in the 1959 plan was estimated to be $\$ 22,500,000$ (TRCA, 2013). The final stage, in addition to the MTRCA initiatives, was an eleven year process initiated by the province to create and implement a flood plain planning policy (TRCA, 2013). This process then allowed for the development of flood plain regulations and the updating of the Conservation Authorities Act. Essentially the flood plain regulations were executed to restrict future development and land use in flood hazard areas thereby reducing possible future flood damage.

During this time, two other major flood control programs were initiated to assist in the implement of this plan. They included the flood forecasting and warning program and the stormwater management program (TRCA, 2000). These programs were designed to monitor watershed conditions including snow, precipitation, and flows, and to issue flood messages across the region's municipalities when they were warranted. As a result of these programs, gauging stations and rainfall observation networks were organized and designed to forecast and warn against potential flooding in the area (TRCA, 2000). With these developments steps could then be taken to minimize potential flood damage. Between 1959 and 1995 major flood control remedial works were carried out. The province thought it best to attempt to control the region's watercourses instead of remove people and infrastructure from flood prone areas or allow the water to run its natural course. Three of the originally planned fifteen dams were constructed in Toronto and surrounding areas and include the Claireville dam in 1964, Milne dam and G. Ross Lord dam in 1973, and two others not initially identified, at Stouffville and in Black Creek at Shepard (TRCA, 2013). In addition to these dams, 12 large scale flood control channels and two major flood dykes were implemented. Over 280 erosion control works have 
also been completed in Toronto and surrounding areas (TRCA, 2013).

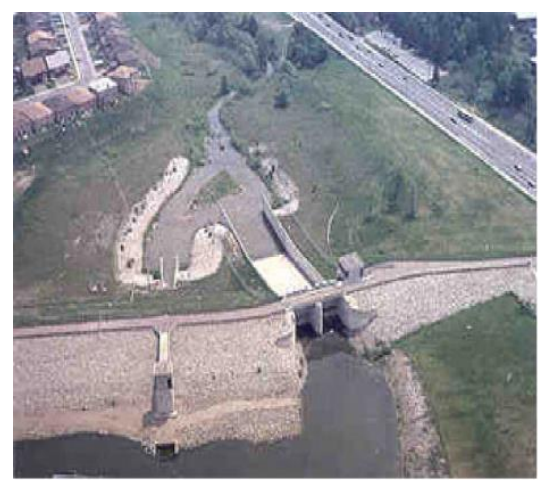

Claireville Dam

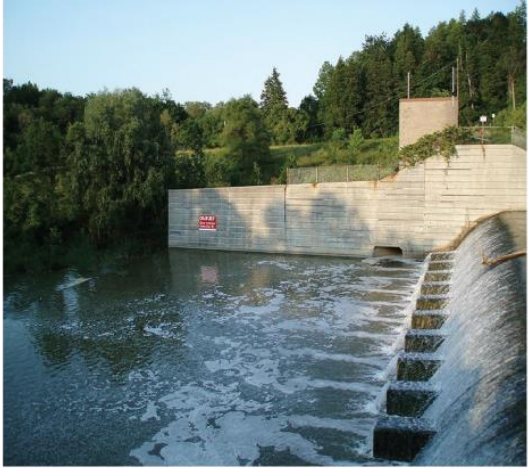

Milne Dam

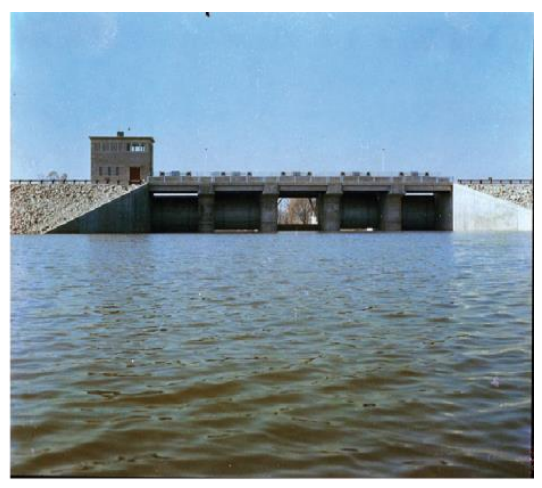

G. Ross Lord Dam

Figure 20: TRCA Flood Control Structures (Source: TRCA, 1997)

Through the land acquisition program, 40,000 acres of land was attained. All of these lands were acquired for flood control purposes and at present a large portion of these lands have been passed on to Toronto's municipal park departments to maintain, manage and provide for an integrated parks system. Benefits have risen through the land acquisitions and include greenspace along each watercourse, social infrastructure and preservation of wildlife habitat (TRCA, 2013). What started as a flood control project helped transform Toronto into a unique and green city with green fingers of park and wildlife habitat extending beyond the city's limits.

\subsection{Turning to Flood Management}

Until the 1960s and 70s, the City of Toronto's approach to flooding was control. Slowly a shift towards flood management instead of control began in the 1980s. As understanding of floods began to deepen, the city shifted to "manage" floods which suggest that floods cannot entirely be prevented or controlled but they must be managed with plans, procedures, and warning systems. A city or region cannot rely on flood control alone through permanent control structures as they will not be effective over the long run (Haeuber \& Michener, 1998). Rather the key is a more informed kind of flood management, one that involves working with the forces of nature instead of simply trying to eliminate them (Haeuber \& Michener, 1998). 
The absence of legislative mandates related to the management of wet weather flow in existing urban areas of Ontario, meant that previous wet weather flow control initiatives were largely driven by local flooding problems and impacts on recreational beach areas (Marsalek et al., 2004). As some source control options and measures, addressed above, were taken and implemented, at present, the issues have mostly been addressed through infrastructure construction and end-of-pipe solutions. While these initiatives had shown significant effort and provided some local environment improvements, it was recommended that a watershed based strategy was required to provide a consistent and comprehensive approach to mitigating impacts of wet weather flows in Toronto and surrounding regions (Marsalek et al., 2004). Flood risk management is the latest approach seen to emerge in flood hazard policy and planning. Flood risk is defined as the expected damage from flood and depends on both the flood probabilities and the flood impacts (de Bruijn, 2007). Previously, discussion on managing floods included land drainage and flood defence, this discussion has now moved towards managing the "flood risk". The need to manage all aspects of water and water use in a systematic manner and also manage land and water on a watershed basis has become a best practice (de Bruijn, 2007). To manage flood risk decision makers need to manage disturbances for both the short and long term (de Bruijn, 2007).

While the initial development of flood management began in the 1960s in Toronto, the official stormwater management program was initiated in 1980. The program first began because of the recognition of the impact urbanization had on the hydrologic cycle (TRCA, 2000). The program evolved from 1980 to include water quality and temperature impacts, source control, and retrofitting of facilities which do not meet current design standards (TRCA, 2000). Since the 1980's the former City of Toronto, developed stormwater policies and undertook studies related to water quality, sewer system and subwatershed management. The City participated in watershed rejuvenation with the TRCA and the Waterfront Regeneration Trust to achieve a Remedial Action Plan (City of Toronto, 2003). 
The City of Toronto initiated the development of a Wet Weather Flow Management Master Plan (WWFMMP) in 1997 to address the impacts of wet weather flow in the region. Specifically, the Plan arose from the Environmental Assessment Advisory Committee report of 1994. The report identified the need for "Wet Weather Flow Master planning on a watershed basis to restore 'beneficial' uses within the watersheds" of the region (City of Toronto, 2003, p. 7). In the creation of this plan the goal was to look not only at site specific wet weather flow issues, but to instead consider the whole natural hydrologic cycle within the context of watershed management and ecosystem protection. The development of the Master Plan followed the planning principles of the Province of Ontario's Environmental Assessment Act incorporating public consultation at key points in the decision making process. Key Steps in the Plan Development (Marsalek et al., 2004):

\begin{tabular}{|c|c|}
\hline Step 1 & -Data gathering, problem definition and policy formation \\
\hline Step 2 & $\begin{array}{l}\text { - Development of the Wet Weather Flow Management } \\
\text { Master Plan }\end{array}$ \\
\hline step 3 & -Implementation of the Master Plan \\
\hline $\operatorname{step} 4$ & - Ongoing monitoring and updating of the Master Plan \\
\hline
\end{tabular}

The WWFMMP was completed in 2003, and a Wet Weather Flow Management Policy and funding mechanism to support implementation of the Plan was also developed at this time. In 2006, the Wet Weather Flow Management Guidelines were developed as a necessary support for the policy. The Master Plan development focused on the area contained within the City of Toronto boundaries, but the initial study extended to include the six major watersheds of the Rouge River, Highland Creek, Don River, Humber River, Mimico Creek, Etobicoke Creek and the lake-based watersheds draining directly into Lake Ontario (Marsalek et al., 2004). Applying the approach of ecosystem management at the watershed scale, urban growth in areas of new development, urban intensification within Toronto, and retrofitting existing urban areas with wet weather flow controls were analyzed and accounted for in the 
development of the Plan. While the development of the Plan took a watershed approach, its implementation is limited to land located within the City of Toronto boundary line (Marsalek et al., 2004). Given this, the City will require support from other levels of government and partnerships with municipalities located upstream through the TRCA, to address wet weather flow impacts on the watersheds which flow through the City and discharge to the waterfront.

Through the implementation of the Plan the City is expected to fulfill its legislative requirements and meet its corporate objectives of ensuring health and safety, infrastructure protection and it must accommodate for future growth (Marsalek et al., 2004). The MNR puts forward three important components of flood management and forecasting in which conservation authorities are responsible for (TRCA, 2004).

Table 2: Components of Flood Management and Forecasting

\begin{tabular}{l|l}
\hline Components & Description \\
\hline Prevention & $\begin{array}{l}\text { Informing planners and the general public about the risks of flooding to promote } \\
\text { proper land use planning, preventing people from living and/or working in flood-prone } \\
\text { areas. Conservation authorities are responsible for predicting flows and water levels } \\
\text { within their watersheds, operating flood control structures, such as dams and } \\
\text { disseminating flood warnings to local municipalities and agencies. }\end{array}$ \\
\hline $\begin{array}{l}\text { In order to protect against flooding, conservation authorities have constructed and } \\
\text { maintain protective infrastructure, such as dams and dykes, or purchase lands located } \\
\text { in hazardous areas. Stream gauges, weather stations, surveys of snow conditions, } \\
\text { meteorological forecasts and computer models are used to forecast potential floods. }\end{array}$ \\
\hline $\begin{array}{l}\text { Emergency } \\
\text { Preparedness } \\
\text { and Response }\end{array}$ \\
$\begin{array}{l}\text { advice to municipalities for the preparation of flood contingency plans and to provide } \\
\text { advice during the emergency response process. In Ontario, conservation authorities, } \\
\text { and the MNR are responsible for forecasting where and when flooding is likely to occur } \\
\text { and issuing flood alerts and warnings to local municipalities, the media, police and } \\
\text { school boards. To facilitate this activity, conservation authorities and the MNR work } \\
\text { closely with Environment Canada, Meteorological Services, who provide the weather } \\
\text { information necessary to make the flood forecasting systems function effectively. }\end{array}$
\end{tabular}

(TRCA, 2004)

This warning system allows municipalities and government agencies to put emergency response plans into operation, evacuate communities, and remove portable property from flood-susceptible 
areas (TRCA, 2004). It also notifies the public of developing or ongoing unsafe lake and river conditions, and allows them to prepare or take precautions.

Benefits expected to be seen through the implementation of the plan over the next 25 years include: "swimmable waterfront beaches; control of combined sewer overflows in compliance with legislative requirements; basement flooding protection; protection of the city's infrastructure from stream erosion; restoration of degraded local streams and aquatic habitat and the reduction of algal growth along the waterfront and improved stream water quality in area watercourses" (Marsalek et al., 2004, p. 73).

\subsection{The Importance of Conservation Authorities: Creation of the TRCA}

The TRCA was formed in 1957 in the aftermath of Hurricane Hazel (TRCA, 2013). The Authority is given power under the Conservation Authorities Act, and is responsible for riverine flood management within its jurisdiction. The Act allowed for the creation of a new kind of agency, watershed-based conservation authorities, which were given a mandate to protect and manage natural resources including water (Conservation Ontario, 2003). This represented the first watershed (an ecosystem-based unit) rather than a politically derived unit to be used as a boundary for managing human activities (Conservation Ontario, 2003). The watershed has been recognized as an appropriate unit of management for at least the last 70 years. A review of international watershed management experience has identified why structuring policy, planning management and implementation on the basis of watersheds makes good sense. These include but are not limited to (Conservation Ontario, 2003):

- Because of its unique properties, water integrates and catalyzes other biophysical processes in air, land and water environments

- Watersheds define distinct biophysical units

- Watersheds are an easily understood ecosystem unit

- The health of rivers and streams is both influences by and illustrative of the health of lands through which they flow

- Water systems demonstrate the cumulative effects of environmental stresses

- Quality of life is directly linked to water quality in watersheds 
- Most management actions can be integrated using watersheds, at some scale, as a common planning unit

- There is strong growing public support for implementation at the local watershed level

The use of watersheds as a management unit has been endorsed by many jurisdictions around the world including England, Wales, Australia, and in many parts of the United States. There is a need for a fundamental shift towards a "place-based" approach using boundaries that make environmental sense and which facilitate a cross-media, cumulative approach (Conservation Ontario, 2003).

The TRCA currently serves approximately one third of Ontario's population of over five million people. At present it is estimated that there are 8,000 structures at risk due to flooding across the TRCA's jurisdiction, which translates to over 35,000 people at risk at 3.1 billion dollars in potential flood damages, not including possible damage to public infrastructure (TRCA, 2013). Thus, the TRCA has a very important role as the authority's main function is to protect people from loss of life and property due to riverine flooding (TRCA, 2013). Its area of jurisdiction was developed by and is comprised of nine watersheds and includes the region's river valleys, Lake Ontario shoreline, headwater areas of the Oak Ridges Moraine, and the Niagara Escarpment.

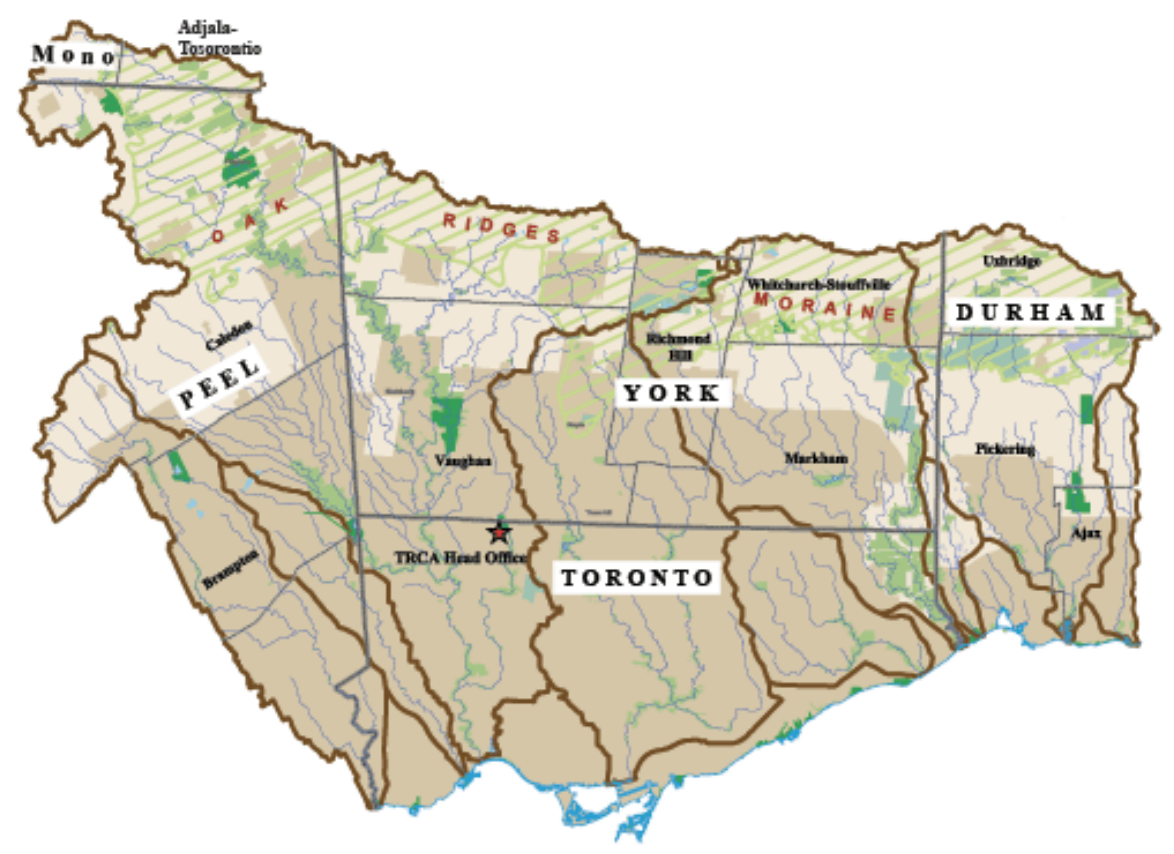

Figure 21: TRCA Jurisdiction and Participating Municipalities (Source: TRCA, 2013) 
The TRCA's flood management service has four unique and interrelated programs which address the issue:

Table 3: TRCA Flood Management Service Programs

\begin{tabular}{|c|c|}
\hline Program & Role \\
\hline $\begin{array}{l}\text { Flood Risk } \\
\text { Management Program }\end{array}$ & $\begin{array}{l}\text { - Produces long term plans for the sustainable management of flood risk in } \\
\text { - TRCA's jurisdiction } \\
\text { - Manages the Flood Forecasting and Warning Centre } \\
\text { - } \text { Issuenitors watershed conditions including snow, precipitation, and flows } \\
\text { - Operates flood control facilities }\end{array}$ \\
\hline $\begin{array}{l}\text { Flood Infrastructure } \\
\text { Program }\end{array}$ & - Maintains TRCA owned flood infrastructure \\
\hline $\begin{array}{l}\text { Hydrometrics Program } \\
\text { (HYDMET) }\end{array}$ & $\begin{array}{l}\text { Ensures the collection, interpretation, and dissemination of water } \\
\text { quantity, quality, and meteorological data that is vital to meet flood and } \\
\text { watershed management needs }\end{array}$ \\
\hline $\begin{array}{l}\text { Data Management } \\
\text { Program }\end{array}$ & $\begin{array}{l}\text { - Responsible for the management, analysis and distribution of TRCA } \\
\text { hydrometric and flood related data }\end{array}$ \\
\hline
\end{tabular}

(TRCA, 2013)

To realize the flood risk in the GTA, the TRCA has indicated that it is necessary to understand four important factors that establish risk - "exposure to the chance of injury or loss" (Martin-Downs, 2013, p.

2):

1. Climate: How prone is the area to severe weather and what type of weather can we expect?

2. Geology: How is our landscape shaped and how do our watersheds store and release water?

3. Policy: What is our tolerance for living near water and who regulates development?

4. Warnings: Do we have effective methods to manage the risks that exist?

Understanding these factors helps to guide how the TRCA manages water and flood risk in its jurisdiction on a watershed basis.

\subsection{Next Direction: Building Resilience}

With increased human stresses on watercourses and the continued sprawl of urbanization, flooding will always be a significant risk. There will always be a need to adapt current flood management policies and procedures moving into the future. Stakeholders such as the municipal, provincial and federal governments, the TRCA, community representatives, and non-government 
organizations will need to work together to reduce risk and best manage future flooding to build a city that is more resilient to future storm events, associated flooding, and climate change.

Resilience has been increasingly used as a means of describing or understanding what cities hope to achieve through planning, policies, programs and design. While this term is commonly used, it is often misinterpreted or misrepresented in the context of planning and policy. It has been found that there is an increasing need to plan for and implement planning and design approaches that improve urban resilience, as shocks and stresses associated with climate change, energy scarcity and aging infrastructure become more prevalent. One way cities can become more resilient is by better integrating natural systems and areas of environmental significance into the urban setting and form.

Resilience is concept first explained by C.S. Holling in 1978, and is defined as " the capacity of a system to absorb disturbance and reorganize while undergoing change so as to still retain essentially the same function, structure, identity, and feedbacks", and is associated with the study of ecology, psychology, management, economics and engineering (Walker et al., 2004, p. 1).

Table 4: Four Critical Aspects of Resilience

\section{Aspects of \\ Resilience}

Latitude

Resistance

Precariousness

Panarchy

\section{Description}

The maximum amount a system can be changed before losing its ability to recover (before crossing a threshold which, if breached, makes recovery difficult or impossible).

The ease or difficulty of changing the system; how "resistant" it is to being changed. How close the current state of the system is to a limit or "threshold." Because of cross-scale interactions, the resilience of a system at a particular focal scale will depend on the influences from states and dynamics at scales above and below. For example, external oppressive politics, invasions, market shifts, or global climate change can trigger local surprises and regime shifts.

(Walker et al., 2004)

As cities are complex ecosystems made of physical and human infrastructure, naturally the term resilience lends itself in describing what cities are trying to achieve through policy, programs, infrastructure and design. Cities have the ability to, or strive to demonstrate adaptive capacity, meaning they are able to anticipate, adjust, and recover from stresses. A resilient city responds to change in a 
way that it is able to retain its basic functions while incorporating new ideas, approaches, policies, and industries. As a result, an improved system of planning emerges, showing its capacity to adapt to shocks and stresses, still maintaining function. While a resilient city or ecosystem has the capacity to return to its previous functions, there needs to be a recognition that it is returning to a new state of 'normal' or an alternate steady state. A city that has recovered from a flood event will never return to its previous state, it has regained its prior functions but will appear and function slightly differently than it did before, this is considered to be its new normal state.

Adaptive capacity is also important in understanding the concept of resilience. The adaptive capacity of a city is closely related to aspects of creativity, innovation, flexibility, and diversity (Walker et al., 2002). Adaptability "is the capacity of actors in a system to influence resilience" (Walker et al, 2004, p. 2). In the case of the city, this amounts to the capacity of humans to manage resilience. C.S. Holling suggests that there are four ways actors can manage resilience: move thresholds away from or closer to the current state of the system; move the current state of the system away from or close to the threshold; or make the threshold more difficult or easier to reach; actors can also manage cross-scale interactions to avoid or generate loss of resilience at the largest and most socially catastrophic scales (Walker et al, 2004).

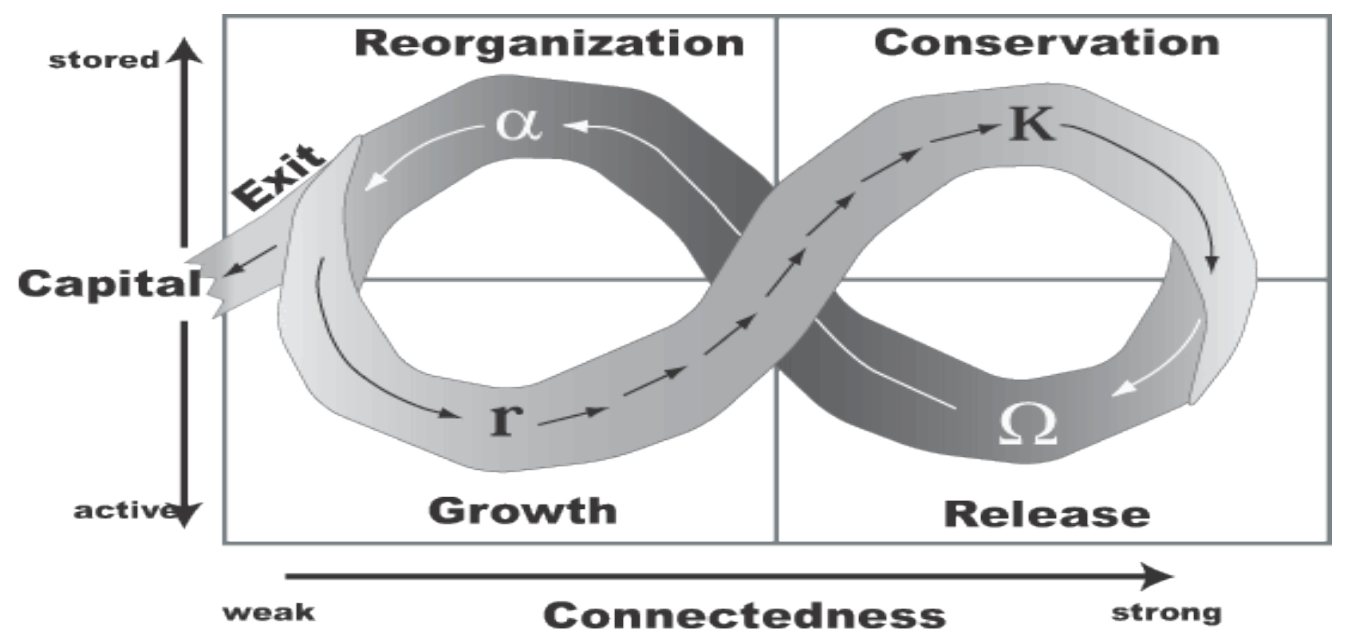

Figure 22: Understanding Resilience: The Four Ecosystem Functions ( $r, \mathrm{~K}, \Omega$, and $\alpha$ ) Organized into an Adaptive Cycle (Source: Holling \& Gunderson 2002) 
Further, "ecosystems are moving targets, with multiple features that are uncertain and unpredictable. Therefore, management has to be flexible, adaptive, and experimental at scales compatible with the scales of critical ecosystem functions" (Walters, 1986; Gunderson et al., 1995, p. 490). Policies and management that apply fixed rules for achieving constant yields, independent of scale, ultimately lead to systems that increasingly lose resilience. This means that these systems break down in the face of disturbances where they previously could have been absorbed (Holling 1986, 1995).

A resilient city is one that focuses on making strong connections between its natural landscape, built form, and actors influencing the process. Going forward it will be important for Toronto's policies, programs, and design solutions to incorporate the concept of resilience in order to continue to grow and build a city that can withstand future flooding and the impacts of climate change. 


\subsection{The Current State: Policy Context}

In the face of climate change and expected increase in extreme weather events and related flooding, it is essential to look at the City of Toronto's policies, plans and guidelines that currently deal with the way water is conveyed and managed throughout the city. The provincial policy context will be briefly provided followed by a closer look at the City of Toronto context, with a special focus on the WWFMMP.

Policy relating to flood management in Ontario is very different than policies in other areas of Canada, and throughout the world (Martin-Downs, 2013). For example, in London, England, development is acceptable in the floodplain and the city has a heavy reliance on flood control or "flood protection schemes" that need to be constructed before a flood event to provide temporary protection (Martin-Downs, 2013). The Federal Emergency Management Agency in the United States regulates development within the floodplian and some landowners are given permission to develop in flood prone areas if they can provide proof of flood insurance (Martin-Downs, 2013). Development rules vary across Canadian provinces, it is however common for development to occur within the 100 -year floodplain.

Ontario's approach to development within the floodplain is an exception. In the aftermath of Hurricane Hazel, the Province's approach was to restrict development within the regulatory floodplain. The floodplain was delineated by applying the precipitation from the Hazel event over each wateshed and then calculating where the flood waters would have reached had the storm been centred over each particular watershed (Martin-Downs, 2013). This approach and floodplain deliniation has often been challenged as overly conservative and careful in managing development. However, it serves extemely well in limiting loss of life and property due to flood risk (Martin-Downs, 2013).

The WWFMMP is seen as the most important city document for guiding and managing water in the City of Toronto. While the document does not specifically deal with flooding, it provides the mechanisms and measures the city must take to manage water for the prevention of flooding. As such, 
this document, related policy and guidelines will be examined to better understand how Toronto is currently managing water and how the city expects to manage it moving into the future.

\subsection{Provincial Policy Context}

Policy planning in Ontario is conducted through a top-down policy framework in which the overarching legislation is established by the Provincial Government of Ontario and then implemented through provincial and municipal planning documents.

The Sustainable Water and Sewage Systems Act was enacted in 2002, and was created to maintain standard water quality across the province. The purpose of the Act is to ensure that municipalities can finance essential water and sewer services and ensure clean and safe drinking water. The Act makes it mandatory for municipalities in the Province of Ontario to assess the costs of providing water and sewage services, and to generate the amount of money needed to operate and maintain them.

The Clean Water Act of 2006 provides legislation towards preventing and protecting drinking water from source to tap. The goal of this Act is to ensure that communities are able to protect their municipal water supplies through the identification of potential risks to local water sources. It aims to provide direction for taking action to reduce or eliminate these potential risks. While the passing of this legislation was a step towards water protection, it does not provide guidelines for stormwater management in Ontario. At the provincial level, stormwater management consists only of voluntary guidances. The Ontario Ministry of Environment produced a design guide that can be used for those interested in stormwater management. While the guide is comprehensive, it is not policy.

The Conservation Authorities Act gives power to the TRCA to control the flow of surface waters for flood prevention, development regulations within its jurisdiction, and provides the authority with area regulations under its jurisdiction. Section 21. (1) (j) identifies the powers and responsibilities of 
authorities with respect to flood management and states authorities powers to control the flow of surface waters and to prevent floods or pollution or to reduce the adverse effects thereof.

The Planning Act sets out the overall framework for how land use planning is to be conducted in the Province of Ontario. The Planning Act establishes the requirement that "no negative impact" be demonstrated where development is proposed within or adjacent to a natural heritage system. The Act addresses flooding and flood management under sections 34. (1) and 50 (3), (5). These sections address development through zoning by-laws and subdivision/part-lot control, and state that it is prohibited to erect structures on land that is subject to flooding. Section 50 gives power to authorities to acquire lands through the MNR under section 24 of the Conservation Authorities Act for the purposes of flood control, bank stabilization, shoreline management, or the preservation of environmentally sensitive lands. The Act takes into consideration requirements for stormwater management, but does not have any binding requirements for design or performance.

The Provincial Policy Statement (PPS), updated and effective April 30, 2014, is issued under the authority of Section 3 of the Planning Act and provides policy direction on the matters of 'provincial interest' that the Act identifies. The PPS addresses stormwater management using the watershed as an instrument for effective planning and urban development. Its policies set out the government's land use vision for how we settle our landscape, create our built environment, and manage our land resources over the long term to achieve livable and resilient communities. The table below highlights key updates related to water management from the 2005 PPS to the 2014 PPS.

Table 5: PPS Update Related to Water Management from 2005 - 2014

\begin{tabular}{|c|c|c|}
\hline Policy Area & Provincial Policy Statement, 2005 & $\begin{array}{l}\text { Provincial Policy Statement, } 2014 \text { (builds } \\
\text { upon PPS, 2005) }\end{array}$ \\
\hline $\begin{array}{l}\text { Healthy, Active } \\
\text { Communities }\end{array}$ & $\begin{array}{l}\text { Promote coordinated, integrated and } \\
\text { comprehensive approach when } \\
\text { dealing with planning matters within } \\
\text { or across municipalities }\end{array}$ & $\begin{array}{l}\text { Promote coordination between } \\
\text { municipalities and other levels of } \\
\text { government, agencies and boards | Policy } \\
1.2 \\
\text { Encourage coordination of emergency } \\
\text { management with other planning }\end{array}$ \\
\hline
\end{tabular}




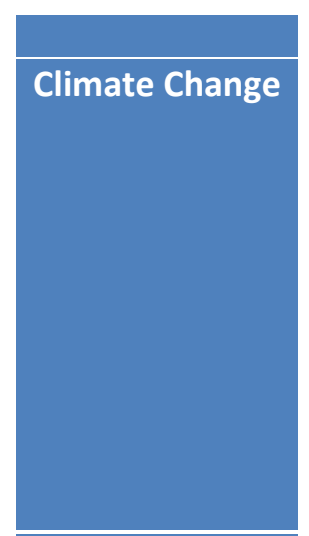

Natural

Heritage,

Wetlands and

Water
- In settlement areas, land use patterns are to be based on densities and a mix of land uses that minimize negative impacts to air quality and climate change

- Indirectly supports climate change by promoting compact built form, intensification, stormwater management, public transit and alternative transportation, and alternative/renewable energy

- Maintain/restore diversity/connectivity of features, and long-term ecological function/biodiversity of natural heritage systems

- Protect significant woodlands and valleylands south and east of the Canadian Shield

- $\quad$ Protect provincially significant wetlands and significant coastal wetlands

- $\quad$ Protect, improve, restore sensitive surface and ground water features and hydrological functions considerations | Policy 1.2.3

- Require the consideration of potential impacts of climate change (e.g., flooding due to severe weather) to support the reduction of greenhouse gas emissions and adaptation to climate change| Policy 1.8

- Encourage green infrastructure (e.g., permeable surfaces) and strengthen stormwater management requirements | Policies 1.6.2, 1.6.6.7

- Require identification of natural heritage systems in southern Ontario (Ecoregions 6E and 7E)| Policy 2.1.3

- Refine area of protection of significant woodlands and valleylands in southern Ontario on an ecoregion basis| Policy 2.1.5

- Protect all Great Lakes coastal wetlands in Ecoregions 5E, 6E and 7E that are not already protected as significant coastal wetlands | Policies 2.1.4, 2.1.5

- Require identification of shoreline areas and support consideration of cumulative impacts | Policy 2.2.1

- Ensure consideration of environmental lake capacity, where applicable| Policy 2.2.1

Section 3.1 of the PPS deals specifically with "natural hazards" of which flooding is considered, and gives policy direction for development and planning authorities. Section 3 of the PPS does not have any marked changes from the 2005 to the 2014 update. It indicates through section 3.1 .2 that development shall be generally directed to areas outside of hazardous lands adjacent to river, stream and inland lakes which are impacted by flooding hazards. Section 3.1 also states that planning authorities shall consider the potential impacts of climate change that may increase the risk associated with natural hazards. Finally, it suggests despite section 3.1.2 development and site alteration may be permitted in certain areas associated with flooding hazard if there are exceptional situations where a Special Policy Area has been approved or where floodproofing standards and protection works standards are demonstrated and achieved. 
Provincial plans such as Places to Grow and the Greenbelt Plan also include policies that support the management of water, but do not specifically address flooding. Sections 3.2 and 4.2 of Places to Grow give direction for municipalities with regard to municipal water and waste water systems. Specifically, the Plan looks to ensure that municipalities are adequately maintaining and improving upon current water management services to be in line with expected increases in population and intensification.

\subsection{City of Toronto Policy Context}

The City of Toronto's Official Plan (OP) is the overarching policy document that all other subsequent city plans conform to. The current City of Toronto OP was adopted in 2010. The OP states that the city has limited discretion in the regulation and management of flooding and suggests that provincial policy generally directs development to areas outside of hazards lands and imposes strict requirements for development that may be permitted in a floodplain. It states that the most important documents for managing hazards in Toronto are the Provincial Policy Statement and the TRCA's Regulation of Development, Interference with Wetlands and Alterations to Shorelines and Watercourses (Regulation 166/06), which it administers in accordance with its Valley and Stream Corridor Management Program. The OP addresses flooding through policies outlined in section 3.1 in the support of strong communities by stating that watercourses be protected from consumption of natural resources and that risks to life, health and safety associated with flooding be reduced. Section 3.5, awaiting a decision by the Ontario Municipal Board, prohibits development within the floodplain, except for buildings and structures in Special Policy Areas, which must be protected from flooding to at least the 350-year flood level. These Special Policy Areas are parts of the community that have historically existed in the floodplain and where stringent control of development would result in significant social and economic hardships to the community. The OP also addresses activities and utilities and services that are permitted within the floodplain. 
The city's OP also addresses wet weather flow and supports the development of the WWFMMP and associated policies and guidelines. It identifies the principles of the Plan to be:

- Rainwater and snowmelt is a valuable resource

- Wet weather flow should be managed on a watershed basis

- Wet weather flow is most effectively managed where it falls, before it enters the sewers, watercourses or the Lake

Finally, it identifies the TRCA as the city's partner in managing the natural environment. It suggests that the TRCA plays an important role in managing Toronto's natural environment by safeguarding and managing watersheds and protecting life and property from flooding.

The city's Climate Change, Clean Air \& Sustainable Energy Action Plan outlines ways that the City of Toronto and its residents are taking action to cut greenhouse gas emissions, clean the air and create a sustainable energy future (City of Toronto, 2013). The Plan was developed to achieve and exceed the Kyoto greenhouse gas reduction target. It represents recognition by the city that climate change will impact its future, and steps need to be taken to encourage Torontonians to adopt more environmentally friendly lifestyles (City of Toronto, 2013). The implementation of the Climate Change Action Plan is important for water and flood management as impacts of greenhouse gases and resulting climate change include rising ocean levels (due to melting of ice and the expansion of oceanic water), and increases in major storm events including flooding (City of Toronto, 2007). This Plan was followed by Toronto's Sustainable Energy Strategy, the Power to Live Green and Toronto's Climate Adaptation Plan, Ahead of the Storm. The Climate Change Action Plan states that Toronto must go beyond mitigation measures and initiate climate change adaptation measures. An adaptation strategy has been developed to protect the city from storms, floods and other extreme weather events related to climate change. Some of the adaptation initiatives to date include A Scan of Climate Change Impacts on Toronto, 2006, by the Clean Air Partnership. Toronto is working with this organization to incorporate climate change into program planning and implementation phases (City of Toronto, 2007). Ahead of the Storm: 
Preparing Toronto for Climate Change is Toronto's climate change adaptation strategy towards a resilient city, and was endorsed by City Council in July, 2008 (City of Toronto, 2013). This document outlines a number of actions that will improve the city's resilience to climate change and extreme weather events. The Plan identifies the following as examples of existing Toronto programs that reduce vulnerability to climate change:

- The Wet Weather Flow Management Master Plan

- Basement Flooding Protection Subsidy Program

- Flood Warning Forecasting

- Emergency Plan

An example of a short term climate adaptation action that was approved for $2008 / 2009$ is the development of regional extreme precipitation intensity, duration and frequency curves and a review of urban flooding issues. The anticipated benefit is that it will assist in improving the ability to design storm drainage infrastructure and the identification of future policy and program requirements for flood protection (City of Toronto, 2008). This action is facilitated by the TRCA, Environment Canada, Conservation Ontario and GTA municipalities. Finally, the Plan makes recommendations for adaptation actions to be taken moving forwards.

Other plans and programs such as Toronto's Emergency Plan and Basement Flooding Protection Subsidy Program are important pieces of policy and implementation but are not overarching pieces that guide flood management. The WWFMMP identified above is a key overarching document guiding water management in Toronto and is central to the focus of this paper. Given its importance it will be examined in detail below.

\subsection{Flood Management Organization in Toronto}

\subsubsection{City of Toronto}

Managing water and responding to flood events in the City of Toronto is shared by various city divisions. The TRCA and the MNR act for the province, while City of Toronto divisions and agencies are responsible for the welfare of Toronto residents and should incorporate water management and flood 
emergency response into municipal emergency planning (City of Toronto, 2012). The MNR and the TRCA are primarily responsible for providing flood related information to the municipality, and the province may coordinate a response in support of municipal action (City of Toronto, 2012).

The City of Toronto's Water division is responsible for delivering safe drinking water, collecting and treating wastewater, and providing stormwater management services. Water Toronto is responsible for assisting in dealing with stormwater throughout the city. It is charged with managing stormwater for two reasons - pollution and flooding. Toronto Water does this through its WWFMMP.

Toronto's Office of Emergency Management helps the city and its residents prepare for and deal with major emergencies and disasters, and it is the coordinating agency for emergency and disaster activities. The office developed Toronto's Emergency Plan which details the methods in which the City mobilizes its resources during a crisis - including flood events. A Risk-Specific Plan for floods was developed in 2012 and is led by the Toronto Office of Emergency Management and the TRCA.

\subsubsection{The Toronto and Region Conservation Authority}

On behalf of the province flood contingency planning in Ontario is shared by municipalities, conservation authorities and the MNR. As with all emergencies, municipalities are primarily responsible for the health and wellbeing of their residents and should include flood emergency response into municipal emergency planning (Martin-Downs, 2013). Conservation authorities and MNR's primary role is the responsibility for operating a forecasting and warning system. The Province may coordinate a response in support of municipal action, but is not required to do so (Martin-Downs, 2013).

The conservation authorities within the GTA have developed a Flood Forecasting and Warning Service for the municipalities and residents within their collective watersheds and on the shorelines of Lake Ontario and Georgian Bay. This service is in place to "reduce the risk to life and damage to property by providing local agencies and the public with notice, information and advice" to allow them to effectively respond to potential flooding and flood related emergencies (Martin-Downs, 2013, p. 3). 
The TRCA, established in 1957 under the Conservation Authorities Act, is a legal entity separate from the City of Toronto, and operates as a non-profit organization with its own "board of directors", the Authority to which the City of Toronto appoints 14 members representing 50\% of the membership. The remaining 14 members are appointed by the Regions of Peel, York and Durham, the Town of Mono and Township of Adjala-Tosorontio.

The TRCA's area of jurisdiction includes 3,467 square kilometres: 2,506 on land and 961 waterbased. The area is comprised of nine watersheds: Carruthers Creek, Highland Creek, Don River, Humber River, Duffins Creek, Rouge River, Petticoat Creek, Etobicoke and Mimico Creek. The TRCA's jurisdiction also extends into Lake Ontario. The TRCA is responsible for monitoring and managing riverine flooding in the City of Toronto. Approximately 35,000 people are within the floodplain in the TRCA's jurisdiction.

The roles and responsibilities of the TRCA during a flood event are outlined in their Flood Contingency Plan. The Plan is intended for all public officials and agency staff who play a role in: “1) prevention and mitigation, 2) preparedness, 3) response and 4) recovery pertaining to flood events" (Martin-Downs, 2013, p. 7). These for categories outline the principles of risk management which have been widely accepted and adopted by Emergency Management Professionals within the province of Ontario (Martin-Downs, 2013). The TRCA's Flood Management Service is addressed under each of the principles laid out below, and is structured to follow the Emergency Management Continuum.

The Flood Management Service at the TRCA operates a flood forecasting and warning system. The TRCA operates under the guidance of the 2008 Provincial Flood Forecasting and Warning Implementation Guidelines (City of Toronto, 2012). This is done by providing local agencies and the public with notice, information and advice so both can respond to potential flooding and flood emergencies (City of Toronto, 2012). The TRCA also monitors its watersheds and weather conditions, issues watershed condition statements and bulletins, notifies appropriate City of Toronto divisions, 
operates Conservation Authority dam and flood control structures, and maintains communication with key City of Toronto staff and MNR (City of Toronto, 2012).

Table 6: Principles of Risk Management

\begin{tabular}{|c|c|}
\hline Principles & Description \\
\hline Prevention \& Mitigation & $\begin{array}{l}\text { - Understanding our risks: climate, geology, watershed response and potential } \\
\text { for climate change. } \\
\text { - Documenting our risks: floodplain mapping, flood vulnerable area database. } \\
\text { - } \quad \text { Limiting exposure to risk: Planning and Development policies. } \\
\text { - } \quad \text { Reducing risk: creating a flood protection strategy for vulnerable areas and } \\
\text { implementing remedial works projects. } \\
\text { - Reducing risk: constructing and maintaining flood control infrastructure. }\end{array}$ \\
\hline $\begin{array}{l}\text { Preparedness (there are } \\
\text { six pillars of } \\
\text { preparedness in } \\
\text { emergency management) }\end{array}$ & $\begin{array}{ll}\text { - } & \text { Emergency Plans } \\
\text { - } & \text { Emergency Operations Centre } \\
\text { - } & \text { Training } \\
\text { - } & \text { Exercises } \\
\text { - Emergency Information/Communication Plans } \\
\text { - Public Education }\end{array}$ \\
\hline $\begin{array}{l}\text { Response (during an } \\
\text { event) }\end{array}$ & $\begin{array}{l}\text { - Flood forecasting (includes issuing flood messages). } \\
\text { - Flood Infrastructure and Hydrometrics operations (operating flood control } \\
\text { infrastructure, e.g., G. Ross Lord Dam). } \\
\text { - } \quad \text { Communications: providing information and advice to response agencies. } \\
\text { - } \quad \text { River watch: providing staff in the field to collect information pertaining to } \\
\text { flooding. } \\
\text { - Human resources: manage staff resources, ensure staff safety. }\end{array}$ \\
\hline $\begin{array}{l}\text { Recovery (after the } \\
\text { event) }\end{array}$ & $\begin{array}{l}\text { - } \quad \text { Risk management: event debrief and lessons learned. } \\
\text { Data management: final storm analysis, continue flood event documentation, } \\
\text { - Hydrometrics - gauge maintenance, gauge network upgrades. } \\
\text { - } \text { Flood control infrastructure - infrastructure inspections, documentation, } \\
\text { repairs and upgrades. }\end{array}$ \\
\hline
\end{tabular}

(TRCA, 2013)

The TRCA issues four different flood messages depending on current conditions or expected events:

Table 7: TRCA Flood Messages

\begin{tabular}{|l|l|}
\hline Flood Message & $\begin{array}{l}\text { Description } \\
\text { Flood Advisory }\end{array}$ \\
\hline $\begin{array}{l}\text { Notifies that the potential for flooding exists within specific watercourses } \\
\text { and municipalities. }\end{array}$ \\
\hline $\begin{array}{l}\text { Notifies that flooding is imminent or occurring within specific watercourses } \\
\text { and municipalities. }\end{array}$ \\
\hline Flood Safety Bulletin & Notifies that unsafe lake, river and channel conditions exist. \\
\hline $\begin{array}{l}\text { Watershed Conditions } \\
\text { Bulletins }\end{array}$ & Notifies of anticipated watershed conditions. \\
\hline
\end{tabular}


(TRCA, 2004)

The "TRCA's new Living City Policies uphold the philosophy of limiting the exposure to natural

hazards to reduce the risk to life and property. In this way, through policy and regulations the TRCA has functionally and effectively decreased risks compared to other regions without such policies" (MartinDowns, 2013, p. 3).

\subsection{Wet Weather Flow Management Master Plan}

The WWFMMP can be seen as the overarching plan used to manage water in the City of Toronto. Much of Toronto's sewer system was constructed 50 to 80 years ago, and is out of date as a result. It was designed by the standards of the day and during its development both weather patterns and population needs were considered. As Toronto continues to grow, increasing pressure is being put on the system, and adding to the strain is climate change (Toronto Water, 2013). As previously outlined in this report, Toronto has experienced more frequent and extreme storms over the past decade. During the heavy rainfall connected with these storms, Toronto's storm sewer system can become overloaded. In older parts of the city, where combined sewers are still used, during large rainfall events the combined sewer system and the sewage treatment plants can be overloaded leading to urban flooding and untreated sewage overflowing into the city's rivers, streams and Lake Ontario (Toronto Water, 2013). In order to help deal with the issues that affect water quality, the City developed the WWFMMP. The Plan is designed to reduce flooding from intense rainfall, and improve water quality and erosion impacts on streams, rivers, and lake water (City of Toronto, 2008). The elements of the Plan are divided geographically by watershed and are referred to by study area:

- Study Area 1: Combined Sewer Service Area

- Study Area 2: Mimico \& Etobicoke Creek Watershed

- Study Area 3: Humber River Watershed

- Study Area 4: Don River Watershed

- Study Area 5: Rouge River \& Highland Creek Watershed 


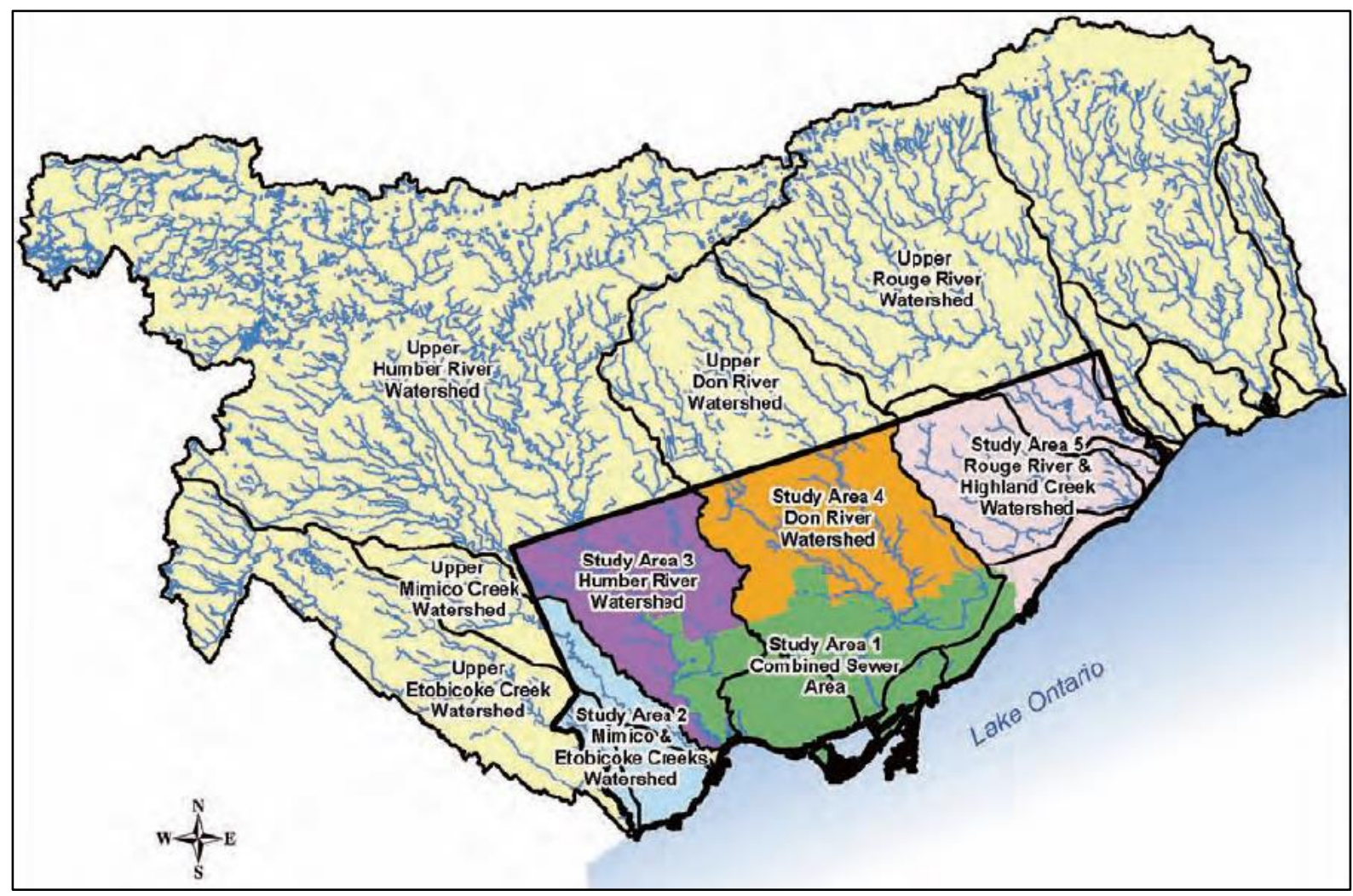

Figure 23: WWFMMP Study Areas (Source: City of Toronto, 2008)

The Plan was based on extensive computer modeling analysis and considered the relationship between upstream and downstream land uses and receiving waters, but specifically focuses on measures that can be implemented in the City of Toronto (City of Toronto, 2003).

As stated above, Toronto City Council adopted the WWFMMP and an accompanying 25-Year Implementation Plan and Policy in 2003. In 2006 Wet Weather Flow Management Guidelines were developed to support and implement the City Council approved WWFMMP and its Policy. The Guidelines are intended to "document the technical requirements for on-site stormwater quantity and quality control for all new development, including infill and redevelopment projects" (City of Toronto, 2006, p. 7). The Plan was based on intensive technical analysis and through input from the WWFMMP Steering Committee. The Steering Committee was comprised of 24 members and included 2 City Councillors, 6 City staff from affected departments, 4 external agency staff and 12 public representatives (Marsalek et al., 2004). It has two parts: 1) A preferred strategy intended to achieve Provincial Water 
Quality Objectives, and 2) A 25 year implementation plan consisting of accelerated projects and programs (City of Toronto, 2003). A 25 year time period was selected to be consistent with the planning horizon for master plans. Through its development it plans to achieve (Marsalek et al, 2004):

- The city's corporate priorities of health and safety (i.e. eliminate basement flooding and provide swimmable water quality at waterfront beaches

- Provide infrastructure protect (i.e. prevent stream and river erosion) and renewal (i.e. eliminate dry weather discharges)

- Accommodate intensification (i.e. provide for growth projected in the city's Official Plan)

- Satisfy legislative requirements to eliminate combined sewer overflows (i.e. satisfy the Ministry of the Environment Procedure F-5-5)

The WWFMMP intends to provide an integrated work program for managing wet weather flow in the City of Toronto using a natural systems approach where practical, and is complemented by an environmental engineering system approach. The City of Toronto states that it was "developed incorporating a new philosophy in wet weather flow management wherein rainwater is recognized as a resource; wet weather flows are to be managed on a watershed basis; and a hierarchical approach to wet weather flow management is to be used" (City of Toronto, 2003, p. 10). The Principles that guide the Plan include (City of Toronto, 2003, p. 8):

1. Recognize rainwater and snowmelt as a valuable resource. Manage rainwater where it falls, on the lots and streets of our city, before it enters a sewer.

2. Manage wet weather flow on a watershed basis using an Ecosystem Approach

3. Implement a hierarchy of Wet Weather Flow practices starting with "at source", then "conveyance", and finally "end-of-pipe" solutions.

4. Inform and Educate Toronto's communities about Wet Weather Flow issues and involve the public in developing solutions.

In developing the Plan an ecosystem management approach was taken on a watershed basis

and studies were conducted on the watersheds as a whole whose boundaries extend past the City of Toronto boundary line. However, the implementation of the Plan is limited to the land area within the City of Toronto. Thus, the city requires support from other levels of government and developing partnerships with upstream municipalities through the TRCA, to address wet weather flow impacts on the watersheds which flow through the city and then discharge to the waterfront (Marsalek et al., 2004). 
The Plan implementation extends across the City of Toronto and encompasses all six major watersheds. The associated costs for plan implementation over 25 years is estimated to be $\$ 1.047$ billion or $\$ 42$ million per year, while operational and maintenance costs to implement the capital projects is approximately $\$ 16$ million per annum (Toronto Water, 2013). The primary goal of the WWFMMP is to reduce and eliminate the adverse impacts of wet weather flow, to protect our environment and improve the ecosystem health of Toronto's watersheds (City of Toronto, 2003). Ultimately it is a long-term plan to protect and enhance the environment and to maintain healthy water bodies in the city.

\section{Growing urbanization with} accompanying increase in hard impermeable

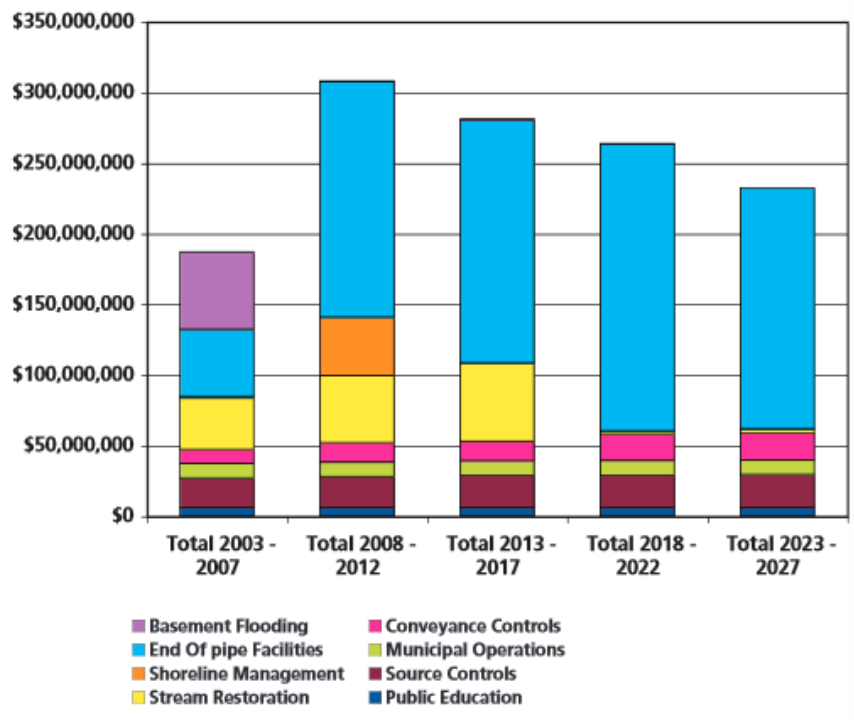

Figure 24: WWFMMP Original Implementation Schedule (Source: City of Toronto, 2008)

surfaces such as concrete, asphalt, and brick dominating large portions of the city changes the way water flows and what it brings with it into the city's storm water system. A lot of stormwater runs off these hard impermeable surfaces and empties into stormwater grates with collected contaminates (dirt, oil, salt, grease etc.), it then travels through Toronto's extensive storm sewer system, 4,500 kilometres in total, to 2,600 outfalls or outlet pipes (City of Toronto, 2013). In some sections of the city stormwater blends with wastewater in combined sewers or flows into sanitary sewers. In some cases, this may cause the city's sewage treatment plants to be overcapacity and untreated water can enter the city's rivers, streams and Lake Ontario. This results in degraded water quality from both an environmental and physical perspective and includes but is not limited to stream bank erosion, loss of aquatic habitat, 
basement flooding and beach pollution (City of Toronto, 2013). This is something that the Plan aims to reduce wherever possible going forward.

To address concerns the Wet Weather Flow Management Policy sets out 13 objective under four major categories to reverse the impacts of overcapacity, deterioration of water quality, and pollution. Policies are stated under each of the categories identified below.

Table 8: WWFMMP Policy Objectives

\begin{tabular}{|l|l|l}
\hline Categories & Objectives \\
\hline Water Quality & 1. meet guidelines for water and sediment quality \\
& 2. virtually eliminate toxics through pollution prevention \\
3. improve water quality in rivers and the lake for beaches that are healthy for \\
swimming
\end{tabular}

(City of Toronto, 2003)

The plan outlines some of the assumed benefits from its implementation which are shown below

(Marsalek et al., 2004):

- Clean waterfront beaches that are healthy for swimming

- Eliminating discharges from combined sewer overflows

- Basement flooding protection

- Protecting City infrastructure from stream erosion

- Restoring degraded local streams

- Improving stream water quality

- Reducing algae growth along the waterfronts and in streams

- Restoring aquatic habitat

A heavy focus within the Plan is its hierarchical management structure: source control, conveyance control and end-of-pipe facilities or solutions. These solutions or control measures are all considered to be structural measures or practices. Source controls are at the lot level and are indicated 
to be the preferred method of management and controlling wet weather flow. They are usually implemented at the beginning of a drainage system or at the lot level. The Policy states that source control should be implemented in the locations identified in the WWFMMP.

Conveyance controls, which include infiltration systems, are a structural management practice that is located within the drainage system where flows are concentrated and are being conveyed along a corridor. Conveyance controls also include pervious pipes, roadside ditches, and other similar systems. The WWFMMP states that roadside ditches and other conveyance methods must be retained and enhanced, and where this is not possible infiltration or exfiltration techniques shall be implemented to achieve the water quality and quantity control targets.

If the city is unable to remove the needed amount of stormwater when it enters the system or flows across it, through source or conveyance control measures, then it will be dealt with at end-of-pipe. End-of-pipe solutions are considered to be a structural practice that is located at the end of the flow route. This is where the stormwaters journey ends before it meets the lake or other water bodies. These exist above ground and include stormwater ponds and constructed wetlands, and below ground facilities such as storage tanks and tunnels. More than 200 end-of-pipe projects have been planned through this document and associated policy, with the majority being above ground projects. Above ground facilities are the preferred type as they are easier to access, maintain and are more cost effective to construct. Where land is a premium in the more densely populated areas of the city underground storage facilities are preferred. The Plan calls for the building of 175 ponds or wetlands, 175 subsurface stormwater management facilities and 44 combined sewer overflow storage and treatment management facilities.

Throughout the life of the plan the city will be monitoring its effectiveness to know whether plan expectations and project targets are being met. Specifically, the city will be looking at different measurements specific to various projects. For example, the city monitors ponds, wetlands and 
shorelines against measured baselines or reference points to see if they are performing as expected.

Both environmental and field monitoring explained above, and 'desktop' monitoring will take place.

While environmental monitoring includes assessing the effectiveness of the proposed and current works, desktop monitoring is intended to track progress in terms of the implementation of the Plan (City of Toronto, 2003). This includes keeping track of the number of downspouts disconnected, kilometres of streams restored, and number of end-of-pipe facilities commissioned, for example (City of Toronto, 2003). The city's main goal in monitoring is to know if their projects are making the planned and expected improvements. The WWFMMP is meant to be a "living" document that evolves and changes over time. Thus monitoring projects is an important component of the plan because it identifies projects that might need to be modified and allows for changes to take place throughout the 25 -year period.

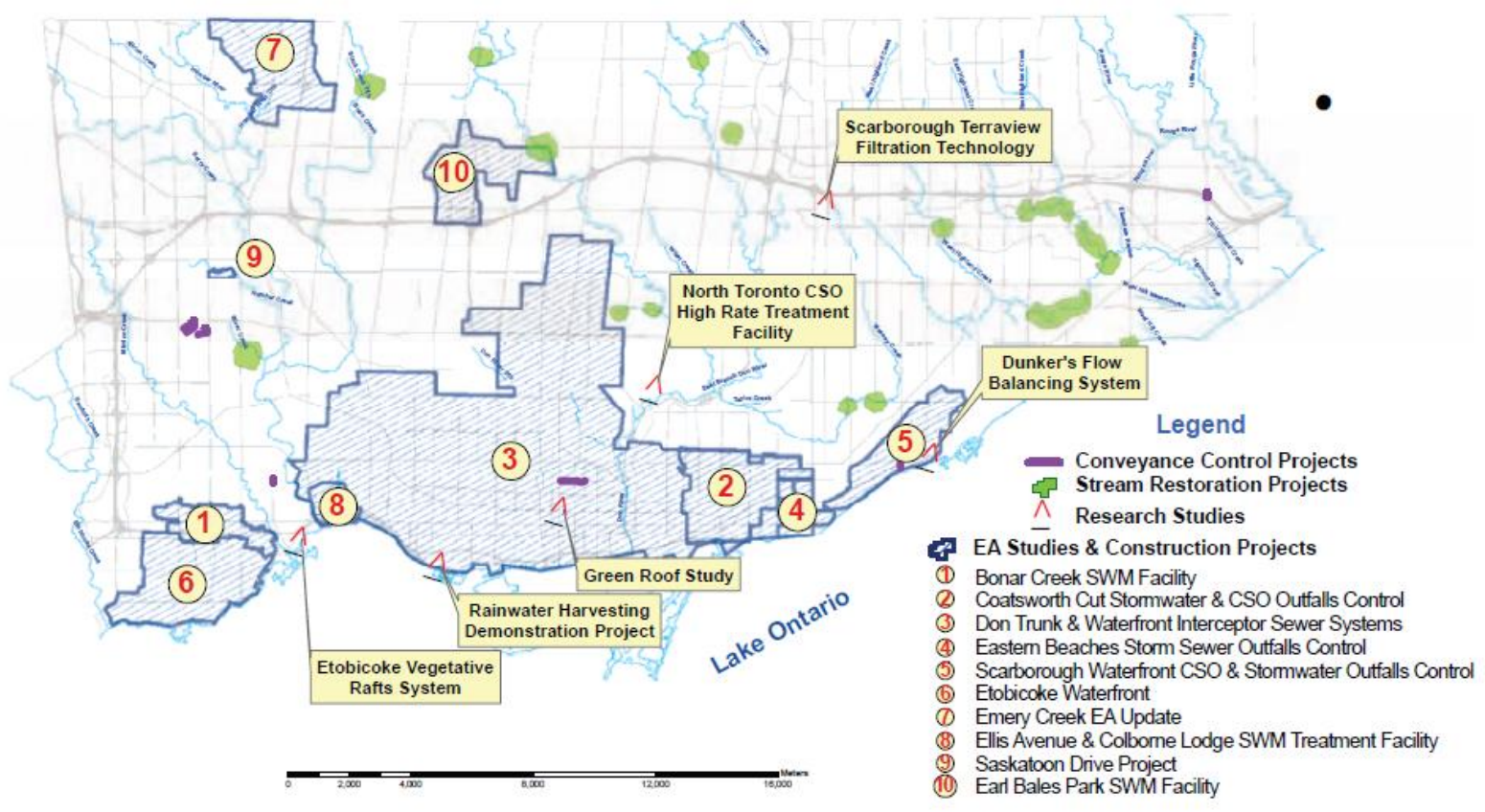

Figure 25: WWFMMP Project Locations (Source: City of Toronto, 2008)

\subsubsection{WWFMMP: Where does it fall short?}

The WWFMMP has shown a marked improvement in the way that water is being thought of, and managed in the City of Toronto. The Plan's development was a long and rigorous undertaking by the 
city and a number of enhancements have been made since its inception, to improve water quality, water quantity, natural areas and wildlife and the sewer systems. While much has been accomplished through the use of policy, programs, and new design solutions, there is room for further improvements to be made in areas where the Plan currently falls short.

In the development of the WWFMMP it was stated that a natural systems approach was used where practical, and that this approach was complimented by an environmental engineering system approach. Consistent with this, the Plan states that wet weather flow "will be managed on a watershed basis" and instead of focusing on specific wet weather flow issues, the plan development considered the whole natural hydrologic cycle within the context of watershed management and ecosystem protection (City of Toronto, 2003, p. 9). In the development of the Plan the city did look at wet weather flows on a watershed basis through the six study areas identified above, however, the implementation of the Plan is not on a watershed basis. Plan implementation is limited to the City of Toronto boundary line, and this is a problem. In the Plan's development the city explicitly states the importance and value of managing water at the watershed level, but falls short by limiting implementation to only the city's jurisdiction. While it too is important to manage water at the municipal level in terms of services to be provided to a municipal tax base, water flows through many jurisdictions and should be managed or planned for by watershed as a unit of management. Water has no fixed location, in the way that solid land masses or buildings do, it flows freely and is not confined to a specific political jurisdiction, and therefore should be managed in this way.

A major problem with this is that support is required from other levels of government and with upstream municipalities. The effectiveness of water management on the part of municipalities lying upstream from Toronto has a direct impact on the city. For water to be effectively managed on a watershed basis in Toronto, the city has to coordinate with the Regional Municipalities of Durham, York and Peel, and the Township of Adjala-Torsontio and Town of Mono. Beyond stating that the city will 
work in coordination with these municipalities through the TRCA, the Plan does not identify how the city plans to work with these municipalities to ensure that water is managed in a manner that is synonymous with the Toronto's objectives, principles, and goals. Large-scale coordination with these municipalities further complicates the problem by having too many actors involved in the management process. A streamlined approach with one unit responsible for watershed management and governance beyond political boundaries is a possible solution that will be further explored in the Best Practices and Recommendations section of this report.

The Plan also identifies that the city will manage water through a hierarchy of wet weather flow solutions "starting with 'at source', then 'conveyance', and finally 'end-of-pipe'” (City of Toronto, 2003, p. 9). In theory, the hierarchy approach is a well-supported method for the management of water. It suggests that management priority is given to at source locations, or effectively where water originates or falls. Water is then first managed at the source or property level before it enters conveyance methods such as stormwater drains or streams, and then finally end-of-pipe solutions such as stormwater ponds. It is significant that the city has recognized the importance of managing water first at source through the mandatory Downspout Disconnection Program, the Green Roof Incentive Program, and tree planting, however, the Plan still has a heavy reliance on end-of-pipe solutions. End-of-pipe solutions are the most costly and infrastructure intensive, and require the most funding for implementation in the WWFMMP compared to at source and conveyance methods. End-of-pipe solutions are also not always carried out in an environmentally conscious manner and often involve storm sewers draining directly into waterbodies. As an example, along the Etobicoke waterfront in Toronto, 30 storm sewers drain directly into Lake Ontario. It is important to note that the city has implemented some innovative end-of-pipe solutions such as the Etobicoke Vegetative Rafts System and the Scarborough Terraview Filtration Technology at Taylor Massey Creek. This is what the city needs to be doing more of, if the focus is still to remain at end-of-pipe. 

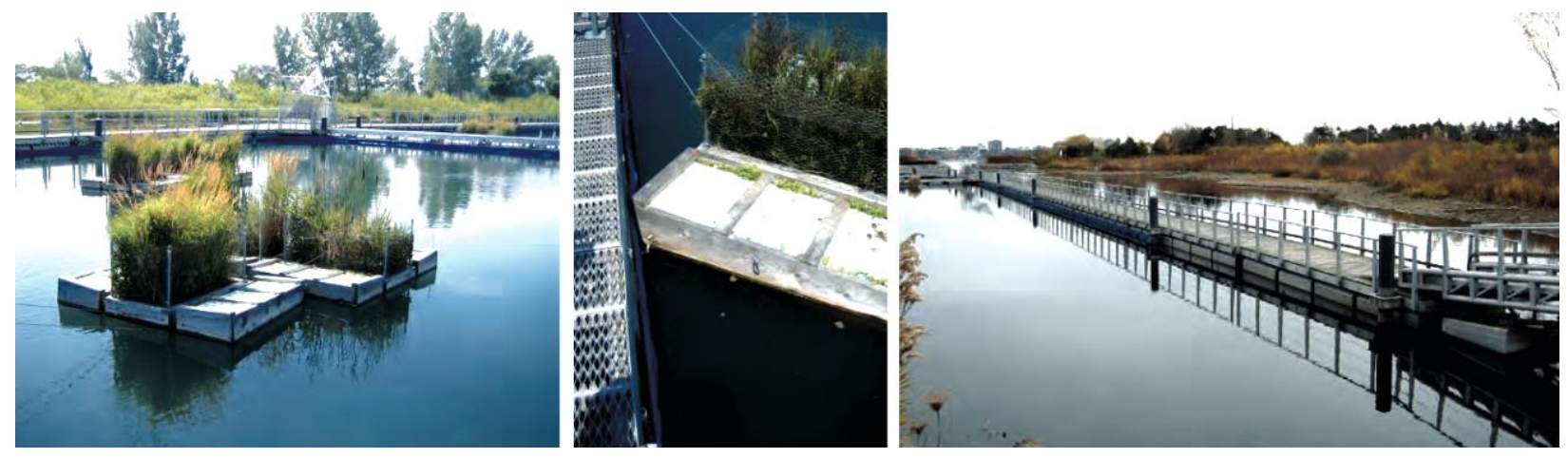

Figure 26: Etobicoke Vegetative Rafts (Source: City of Toronto, 2008)

Climate change and the concept of building resilient policy and design measures to combat Toronto's changing climate is not addressed in the WWFMMP. The Plan was implemented in 2003, and since this time the city has taken measures that relate wet weather flow management and climate change, but the WWFMMP and its policy and guidelines do not address climate change and its impact on wet weather flows in the city. Similarly, planning for the way water is managed in the future or the need to change the way we manage water moving into the future with respect to climate is not addressed in the Plan and accompanying policy or guidelines. There is no direction for managing water in light of climate change, or supporting policy to guide the way the city will address potential changes in risk for flooding moving into the future. The Plan and policy also do not mention or specifically address flooding or its impacts, but do suggest that flooding is a possible result of not managing water successfully. The city does address the link to climate change in a 2008 update report on the implementation of the WWFMMP. In this report it states that the WWFMMP is "an excellent example of an adaptive measure that enhances the resiliency of the system" (City of Toronto, 2008, p. 16). As a result of the impacts seen from climate change and an increasing number of severe storm events, the original 25-Year Implementation Schedule in the WWFMMP was updated to take new priorities into consideration, however it does not address specific changes that were made and a new implementation schedule was not made available. The 2008 report on implementation also suggests that when looking at climate change adaptation strategies for Toronto, the single most relevant policy is the WWFMMP. 
While it addresses the fact that the Plan was not initially developed to respond to climate change, it does however suggest that "it can be seen that Toronto's Wet Weather Flow Management Plan is one of the world's leading climate change adaptation strategies being implemented today" compared to what other cities are doing (City of Toronto, 2008, p. 17). To support this statement, the report outlines the components of the 2003 Plan and suggests that they are important for climate change adaptation, but does not detail specifically how.

In order to effectively manage water and build a city that is resilient to climate change moving into the future, it is imperative that policies related to wet weather flows and their management have a link to climate change and building resilience. Policy that can speak to adapting to change and possible changes in the way water flows across the city's landscape will be important going forwards because no matter how much we plan, the future is still uncertain.

The implementation section of the Plan lists projects to be implemented over the next 25 years until 2027, and aims to achieve the moderate level of targets established. It is stated in the Plan that it will be reviewed and its effectiveness in achieving the targets will be assessed in five year increments allowing for adjustments to the Plan if necessary. The Plan suggests that regular updating will also permit a review of new and emerging technologies for their incorporation into the Plan. Environmental monitoring and Plan review are included in the WWFMMP Implementation Plan.

The city initially kept up with its promise for reporting every five years and produced the Wet Weather Flow Master Plan: The Plan in Action, a 5-Year Summary Report, however, nothing since this 2008 report has been produced. The 2008 report provides a comprehensive overview of project status and completion and suggests that the 25-year implementation schedule for the Plan has been updated, but does not indicate how. The 2013 mark for an implementation update and report has been surpassed. The city does not currently provide any information on their website as to the current status of implementation or when a report will be produced. The city is not being accountable to the public in 
this instance. This is concerning, and through a media scan related to the Plan and its implementation, ward 31 Councillor Janet Davis stated in an article published by the Globe and Mail that much of the planned wet weather flow project spending has been delayed indefinitely (Lorinc, 2013). She also made a statement on an online profile that the budget for the project moving into the future was cut by $\$ 1.1$ billion in 2013, and stated that the Plan is five years behind schedule, but does not provide a reason beyond a budget cut. Her statement has not been supported by City of Toronto staff reports or documents as this information has not been made readily available. However, the 2014-2023 City of Toronto budget indicates that $\$ 33.336$ million will be provided to support the implementation of the WWFMMP in 2014, indicating that funding has been cut from the required $\$ 42$ million per annum (City of Toronto, 2014). The allocation for Wet Weather Flow projects for the 2014-2023 time period has been decreased by a total of $\$ 86.384$ million or $13 \%$ from $\$ 656.680$ million to $\$ 570.296$ million, as a result of the deferral of the Don and Waterfront Trunk combined sewer outflow project by one year (City of Toronto, 2014). Given this, it might be assumed that progress and implementation has come to a halt and therefore monitoring and reporting too.

While there are areas where the WWFMMP falls short from its goal and intended objectives, the Plan and its policy and guidelines are a big step forward towards effectively managing water in Toronto, and can be an example to other Canadian municipalities. Best practices in flood risk management will now be explored to provide a foundation for the recommendations for improvements to the current structure of flood management in the city. 


\subsection{Best Practices in Flood Risk Management}

\subsection{Considering the Short and Long Term}

To effectively manage flood risks, decision makers have to manage disturbances in both the short- and long-term (de Bruijn et al., 2007). In the short term there is a need to cope with extreme peak discharges and storm events resulting from climate variability. While in the long term effects from continuous trends, cyclical changes and variance in climate are probabilities in the future, they need to be taken into account today. Today, flood risk management should not be only concerned with managing extreme rainfall events but also about influencing the interaction between these events with the river and the flood prone region (de Bruijn et al., 2007). Thus, flood risk management must also consider changes in the physical and socio-economic characteristics of flood-prone areas in its long term strategies. Changes in norms, values, population increases and land use are important in the choice of a flood risk management strategy and should be considered.

\subsection{Systems Approach}

Managing flood risk has much to do with uncertainty and therefore requires a management system which not only improves the city's ability to cope with extreme rainfall events and flooding, or peak discharge events, but also an understanding of the change in the severity and frequency of these events overtime from the effects of climate change is needed (de Bruijn et al., 2007). Therefore a systems approach must be used and applied to the management of flood risk. A systems approach is explained "where the system consists geographically of the river system, the catchment and flood prone area and conceptually of two sub-systems based on the physical and socio-economic characteristics of this area" (de Bruijn et al., 2007, p. 63). It must also be recognized that the system is dynamic and is constantly changing state due to the changing relationships between socio-economic conditions (households, companies, institutions, economy, and population characteristics), physical conditions (geomorphological, ecological, hydrological and structural), and to system disturbances such as extreme 
rainfall events or the longer term changes such as a changing climate (de Bruijn et al., 2007). It is here where the system is looked at in its entirety and is managed on this basis. This approach has been considered to be part of the holistic approach which is explained in detail below.

\subsection{Integrated Approach}

An integrated approach to flood risk management is the combination of flood risk management measures. These measures are described as either structural or non-structural. Structural measures aim to reduce flood risk by controlling the flow of water both outside and within urban areas. They complement non-structural measures such as better planning and management of urban development. Structural and non-structural strategies do not exclude each other, and most successful strategies in flood management combine both types (Jha et al., 2012). However, it must be recognized that as both urbanization and climate change accelerate there will be a need to move away from an overreliance on hard-engineered defenses towards adaptable and incremental non-structural solutions (Jha et al., 2012). It is important to note that structural measures are not only hard-engineered structures such as flood defenses and drainage channels, but also natural and sustainable alternative measures such as wetlands and natural buffers. Alternative measures are increasingly being seen as desired, as they reduce environmental impacts and are more cost effective and sustainable over the long term. Given that there will always remain a residual flood risk, there is a need to incorporate non-structural measures into all flood management strategies. Non-structural measures are important because they manage risk by building people's capacity to cope with flooding (Jha et al., 2012). Measures may include warning systems, forecasting systems, flood avoidance through land use planning, improvements to building design and construction.

There is also a need to integrate flood risk management into land use planning and management in order to minimize risk and cope with the impacts of flooding. While new development within the flood plain is not permitted in the City of Toronto, there are instances where development 
has been allowed if the necessary structural flood protection measures are constructed. This is where flood-receptive design can be employed. As urbanized centres become more densely populated, it becomes more important effectively utilize limited land resources through dually functioning flood infrastructure (Jha et al., 2012). This might be the creation of basins which store flood water for outflow control when needed. At other times these basins can be used for purposes such as leisure facilities. Surface water management through the creation of wetlands, environmental buffer zones and other greening measures can protect buildings and infrastructure and also produce environmental and health benefits. Some benefits might include reducing the urban heat island effect and level of $\mathrm{CO}_{2}$ emissions (Jha et al. 2012). Integrated urban flood risk management strategies are designed to fit with waterrelated planning issues and should be part of the overarching plans such as those for climate change adaptation.

\subsubsection{Multi-purpose retarding basin in Japan}

Japan has had a long history of flooding and extreme weather events, and has initiated an integrated flood management approach. The Tsurumi River Basin in Japan spreads from Machida City through to Tokyo Bay. This area of Japan has always been prone to river flooding. In the 1980 s a comprehensive flood control plan was developed and implemented with a protective level of a 150-year flood event (Jha et al., 2012). Part of the plan was the construction of a multi-purpose retard basin which stores water from the river and releases it through controlled outflows and acts as structural measure of flood management. At times when this is not occurring the area is used for leisure purposes and includes an international sports stadium. After a flood event that water is drained through a spillway into the Tsurumi River. An information centre as well as notice boards in the basin serve as a communication mechanism for the general public and provide early warning information (Jha et al., 2012). This acts as a non-structural method of flood risk management. From this example it was found 
that measures must effectively utilize limited land resources available and be integrated within land use plans and procedures.

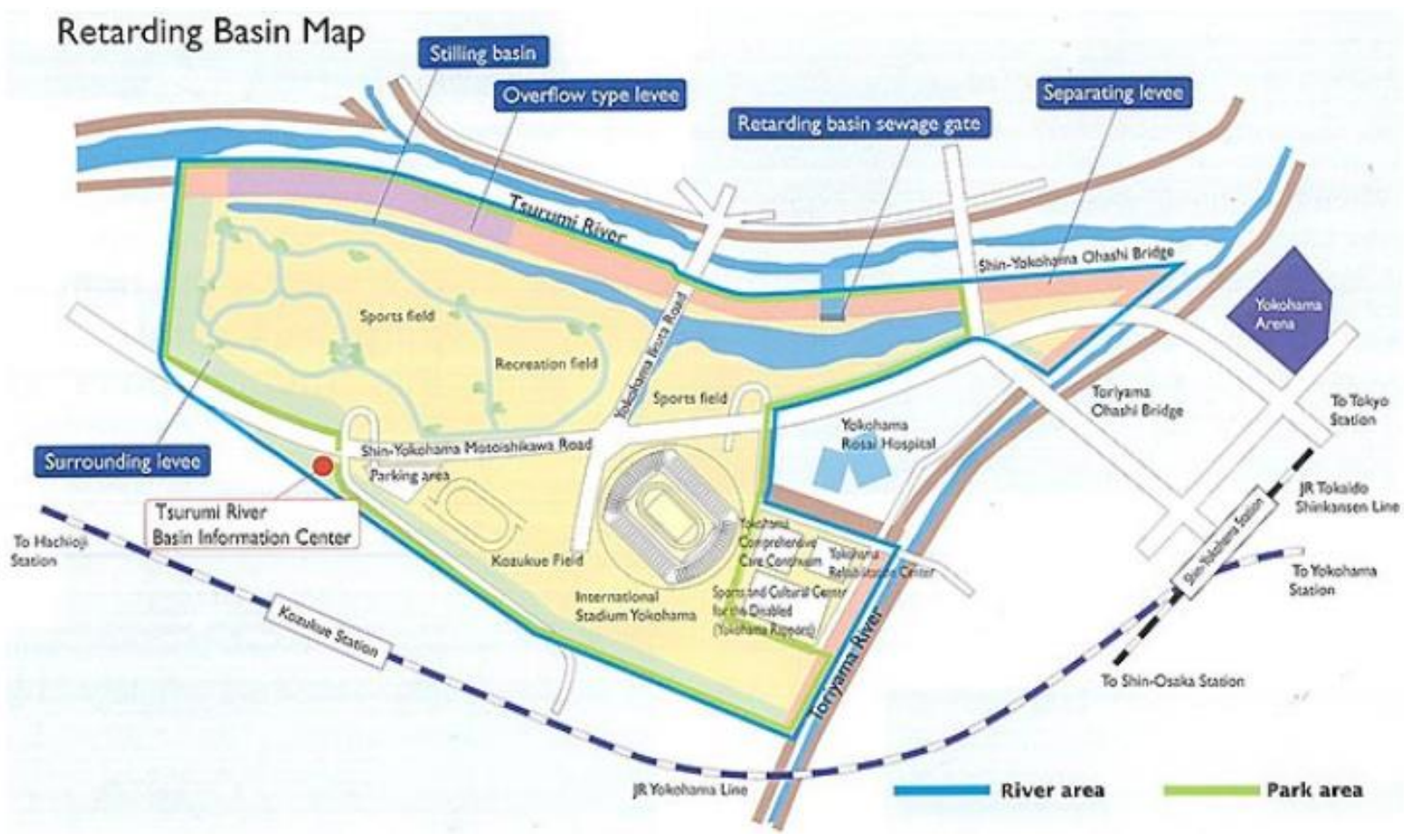

Figure 27: Multipurpose Retarding Basin Japan (Source:

http://www.japanriver.or.jp/EnglishDocument/DB/file/004\%20Kanto\%2023/02.htm)

\subsection{Making room for water: Holistic Approach}

The $20^{\text {th }}$ century saw many countries around the world using water constraint mechanisms such as the channelization of rivers to drain water as quickly as possible. Rivers were treated as production factors, navigation channels, and sewers. These mechanisms were used to keep water away from people. A holistic, sometimes referred to as system-wide approach to water management has been explored in many countries and include the presupposition where symbolic co-evolution between water and land use exists (Odum, 1971). Holism is a central tenet of systems thinking and suggests that "the whole is greater than the sum of all its parts" (Trippett \& Griffiths, 2007, p. 392).The language used to describe this approach is often to the effect of "making space for the river" which implies that river management become intertwined with other domains such as urban planning, ecological restoration, or 
recreation. Making space is a move from vertical flood defenses to horizontal expansion and from vertical top-down management to a more egalitarian form of multi-actor network governance (Warner et al, 2013).

Making space first means making mind space. This is to say that we need to increase and expand the space with which we think about river basins, waterfront and systems (Warner et al., 2013). They need to be more inclusive and there needs to be involvement of other stakeholders beyond the technical experts. This approach involves a broadening of problem definitions and future solutions. These dynamic solutions build with nature and people rather than technical fixes. It also opens opportunities for developing innovative adaptation measures incorporating new instruments and technologies for floodwater management (Warner et al., 2013).

The space for the river concept is a resilience (bouncing back, safe-fail) rather than a resistance (defense, fail-safe) approach to flooding (Warner et al, 2013). Currently, fail-safe measures are in place a system or plan comes into operation in the event of something going wrong or mechanisms are in place to prevent such an occurrence. Whereas safe-fail seeks to reduce disaster risk but accepts that there will always be a residual. Thus to say that it accepts that flooding may occur now and again, and given this it seeks to explore social and ecological pluses of flooding and aims to mitigate the minuses. Such "risk acceptance" with flood hazard then brings possibilities for public participation. It also brings possible negatives such as stakeholders not happy with solutions that request them to accept risk and dynamics of uncertainty. Finally this approach promotes breaking down barriers between different sectorial policy domains like flood risk management, urban development and restoration of natural values (Waltner-Toews et al., 2008; Warner et al., 2013).

\subsubsection{Swiss Resilient Culture}

Until the end of the 1970s the Swiss flood protection system was oriented towards the idea of correcting running waters (Furrer, 2002). Pressure for change away from the traditional system grew 
from a consequence of the public reception of ecological issues in political, legal and administrative contexts. The policy More Space for Running Waters was developed in the 1990s by the Swiss Federal Office for Water and Geology together with other federal organizations, aimed to secure the spatial requirements of running waters. A further aim of the new framework was to develop a participative culture to bring together acting at all levels of government (Furrer, 2002). This initiated a flood resilience culture and people in Switzerland began to accept that their properties may flood from time to time.

\subsubsection{Zurich Day-lighting Program}

The City of Zurich, Switzerland undertook a day-lighting program to aid in separating clear extraneous water from the sewer system. During the last 130 years of the city's development and construction, about $100 \mathrm{~km}$ of previously open waters disappeared from the surface. The objective of avoiding diversion of stream water into the sewers led to the idea of reopening and revitalizing brooks and streams using them as a part of a separate clean water system (Conradin \& Buchli, 2004). This concept of day-lighting provides a solution to the problem faced by many communities, as the traditional way of coping with water and wastewater was to combine them into the sewer system. The reopening or day-lighting of streams is an ideal solution from an economic, ecological, and esthetic point of view (Conradin \& Buchli, 2004). It also allows the waters to run their natural courses and not only be visible during storm events over roads and impermeable surfaces.

\subsubsection{The Netherlands: Making Space for the River program}

The history of water management in the Netherlands is an example to many countries around the world. Through their history the Dutch first resisted water, they went through numerous setbacks, which took hundreds of thousands of lives, and they rebuilt their land by reclaiming land from the sea. They did this by diking newly formed land and by keeping the water from rivers and the sea at a safe distance. The Dutch water management system has evolved from a system of locally organized water 
boards which depended on citizens, land owners and the nobility to a technocratic multi-level governance system which now relies heavily on expertise and long-term budgeting (Lintzen, 2002).

In a response to changing climate, dehydration, and soil subsistence, a new paradigm emerged in Dutch water management which promotes living with water and accommodating water within buildup areas. Major drivers in this policy change and way of thinking were the riverine near-floods of 1993 and 1995. It was also accompanied by a new trend towards more collaboration between public, private and societal actors in governance processes (Edelenbos et al., 2013). The Space for the River program was developed in response to flood risk, and is guided by centrally imposed flood safety standards. Space for the River, a set of 39 river projects meant that decentralization of river intervention planning took place. Provincial and local authorities were given free rein to develop ways of making space, as long as safety standards were kept up. This evolving management allowed provinces and municipalities to pursue regional development and made for the incorporation of river projects, housing development, and traffic congestion relief (Edelenbos et al., 2013). Space for the River created a balance between flood safety, environmental values and urban or regional development (Warner \& Van Buuren, 2011).

The program Waalweelde provides another example of a conscious regional attempt to enlarge the scope for river development options along the river Waal, and to bring landscape architecture and other creative disciplines to combine flood risk management with branding the river as a nice place to be (Scholten, 2010).

\subsection{Resilient Policy Design and Governance}

While there has been a significant increase in the number and types of laws, policies and programs aimed at managing natural systems, there still remains a substantial gap between the formal intent of these policies and their actual effect on natural systems (Dale, 2001). Some of the gaps that exist in implementation can be accounted for by the inadequacy of organizational structures and the administrative processes concerning their management. Some of the main organizational problems can 
be issues of fragmentation, jurisdictional gaps, polarization of interests, jurisdictional conflicts, piecemeal and uncoordinated policies, conflict of resource uses, lack of coordination, trust, communication, and collaboration (Dale, 2001). It has been found that the more agencies responsible for the management of natural systems, the greater the risk of interdepartmental conflict, thus causing a greater need for interagency coordination and communication. Because of this structure, significant gaps and time lags in implementation of the management efforts exist. Adding to organizational structure issues are the continual changes in the environment and social conditions that further reduce their ability to manage effectively. At present there is a fundamental mismatch between the structures, processes and functioning of these organizations and natural systems, which limits the ability to both respond effectively to warning signs from ecological systems and to act in collaboration with them (Dale, 2001). This further complicates the ability of organizations to link knowledge of these natural systems to policy and that policy to action (Westley, 1995).

We need to move from closed to open policy-making processes; from single sector and domestic to issues that are transdiciplinary and global; from government as controller and monitor to government as catalyst and leader;...from policy analysts as technical specialists to policy analysts as individual members of transdiciplinary teams; from management that is primarily vertical to management that is both horizontal and vertical;...from a horizon that is short-term and reactive to one that is long-term, proactive and multiple in time, place and scale; and from adaptive, reactive management to proactive, co-evolutionary management (Dale, 2001, p. 146).

To ensure a more adaptive approach is taken towards the management of natural systems, managers should minimize formal planning procedures where possible to allow for management systems to be adaptive to ecosystem dynamics (Westley, 1995). Further, it is important to understand that no one organization, even in the case of the least jurisdictionally complex ecosystem, can solve the issues related to ecosystem management alone. These are large problem domains and require interorganizational collaboration, something that society is generally weak at (Westley, 1995). 
Resilience policy design and planning often stem from the concept of sustainable development that emerged as an environmental policy concept in the last 20 years. The concept of sustainable development was put on the table by the Brundtland Commission by formulating the classic definition of sustainable development, namely, development that seeks to meet the needs and aspirations of the present without compromising the ability to meet the needs of the future (World Commission on Environment and Development, 1987). Major obstacles to sustainable development can be reduced to three categories (Gallopin, 2002):

- Willingness - described as a lack of political will to implement those changes that are necessary

- Understanding - lack of understanding of the behavior of complex systems - this often results in a failure to address the relevant linkages within and between systems and across scales

- Capacity - insufficient capacity to perform the actions and changes needed - inadequate institutions, lack of financial resources, weak infrastructure, unskilled human resources, etc. 
In seeking sustainable development and management of natural and human made systems we must overcome these obstacles of lack of willingness, understanding, and adaptive capacity. New ideas and new approaches will be required. There will need to be an intersection between these domains and what is physically possible and feasible (Gallopin, 2002).

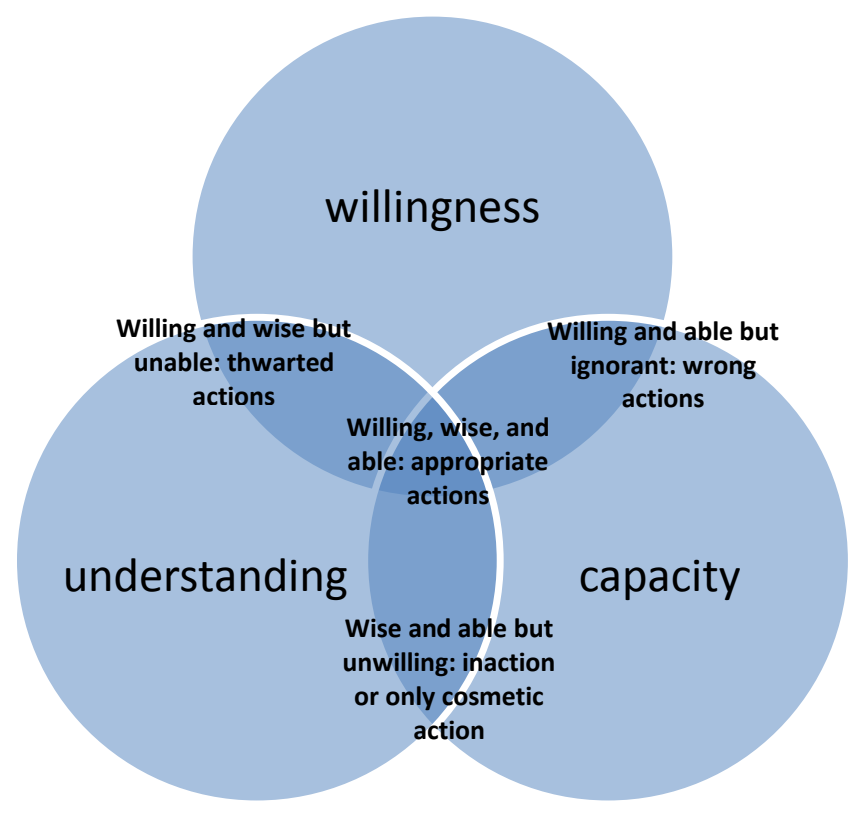

Figure 28: The three pillars of decision making for sustainable development. Intersections of these characteristics determine types of actions taken. (Gallopin, 2002)

Finally, it is important for decision-makers to make decisions that minimize whole-life costs and maximize environmental gain while also ensuring that communities are protected from flooding both now and in the future (Gallopin, 2002). This involves the recognition of flooding from all sources, and managing flood risk in a comprehensive manner. There needs to be an understanding of the role that individual assets play with a larger asset system; impact of uncertainty on the decisions made; and identifying optimal investment strategies (Gallopin, 2002). This form of governance is a whole-system, whole-life approach to design, management and planning and is in contrast to the constrained engineering standards approach in the past (Zevenbergen \& Gersonius, 2007). Policy related to flood management needs to be resilient and flexible, and decision-makers need to accept that the future is 
unknown. Accepting this and embedding it within the broader planning and policy framework will allow for strategies and infrastructure to be developed that reflect the concept of uncertainty.

\subsubsection{Rebuild by Design and Water Management in New York City}

New York City's waterfront plays a vital role as a first line of flood defense and in managing flood risk and protecting the city from the impacts of climate change and future sea level rise (Aerts \& Botzen, 2011). The city has now begun to recognize that water has always, and will always continue to shape its land. As a city exposed to the ocean, New York has always faced risks from severe storms and coastal flooding, most recently experienced when Hurricane Sandy struck New York and New Jersey on October 26, 2012.

In 2009, the Office of Emergency Management led the development of New York City's Natural Hazard Mitigation Plan which assesses the city's vulnerability to coastal erosion, flooding, coastal storms, and identifies mitigation measures to be taken (Vision 2020, 2011). The Plan represents a partnership between thirty-nine city, state, and federal government authorities, and also combines input from the public and private sectors. The city also initiated a citywide multi-agency initiative to create a vision for its shoreline. The Waterfront Vision and Enhancement Strategy was then established with two components: Vision 2020: New York City's Comprehensive Waterfront Plan, and the New York City Waterfront Action Agenda (Vision 2020, 2011). This system of management is further advanced and synchronized between various levels of government and private corporations compared to the flood management plans and mitigation measures found in other cities of similar size and risk level (Aerts \& Botzen, 2011).

Building resilience to coastal storms and anticipated flooding in the future does not lend itself to quick solutions. Historically, strategies to divide water from land have been used to mitigate this problem, but this approach will not be adequate with climate change and sea level rise (Aerts \& Botzen, 2011). The city has realized that going forward certain risks are unavoidable, and instead they must 
identify and manage risks, not remove people from them entirely. To act on this new way of thinking, the Hurricane Sandy Rebuilding Task Force and the U.S. Department of Housing and Urban Development initiated the Rebuild by Design competition. This competition was developed to find better ways of implementing designs, informing policy to build resilience, and to better protect residents from future climate change events. The design teams engaged in research, analysis and outreach which led to more than 40 design opportunities, of which 10 moved forward to the final phase where winning design solutions may be implemented. Below is an image from the WXY/West 8 team proposal.

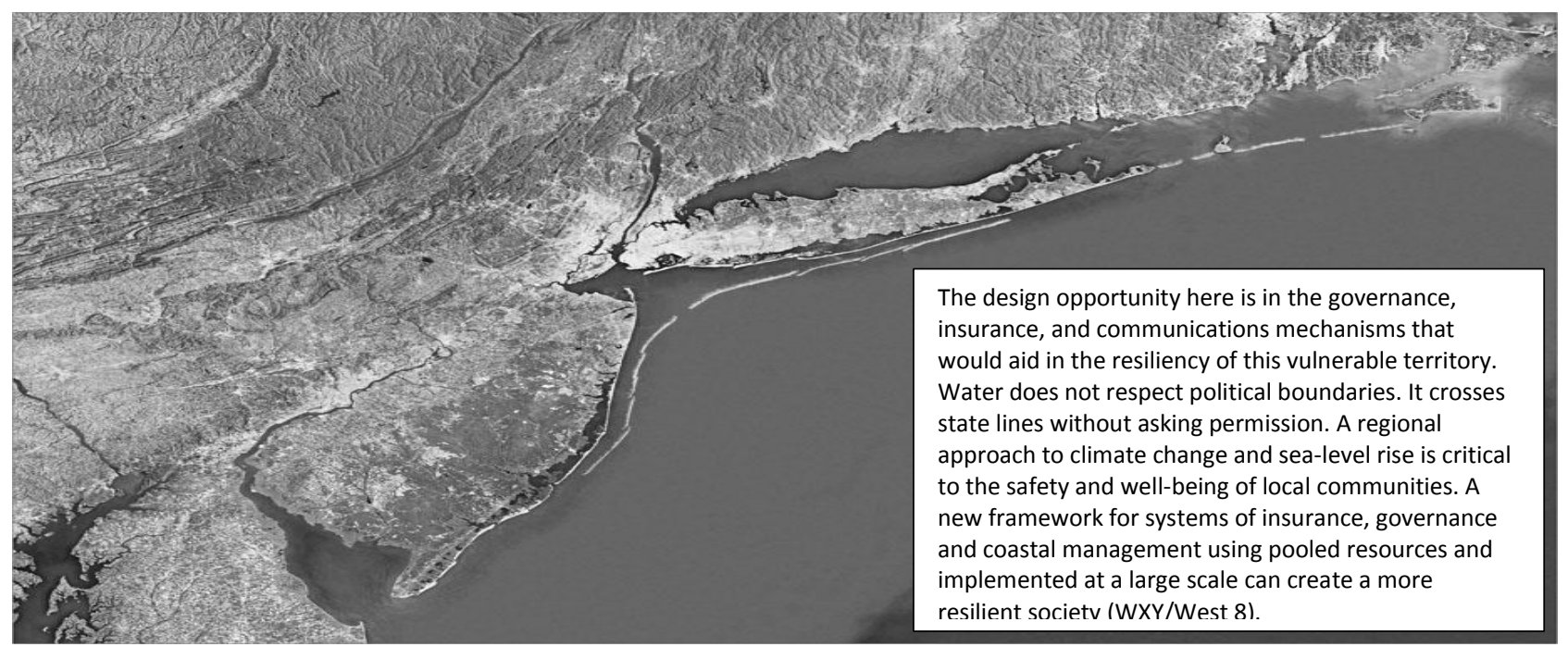

Figure 29: Designing with Nature for the Future of the Mid-Atlantic Coast: A regional view of the proposed barrier islands ranging from New Jersey to Rhode Island (Source: Rebuild by Design: WXY/West 8)

\subsubsection{England Flood Management Structure}

The Pitt Review conducted in 2008 into the large-scale flooding in 2007 in England, concluded that more clarity was needed regarding the roles and responsibilities of the different organizations responsible for managing flooding from all sources (Jha et al., 2012). The subsequent Flood and Water Management Act of 2010 assigned the strategic overview for all sources of flooding and coastal erosion to the Environment Agency (in England) and the responsibility for local flood risk was assigned to Lead Local Flood Authorities (Jha et al., 2012). 


\subsubsection{Water Management in the Murray-Darling Basin}

Murray-Darling Basin is found in south-eastern Australia and includes the major settlement areas of Australia's capital Canberra, Tamworth, Wagga Wagga, Albury, Bendigo, Renmark and Mildura. This area supports more than two million people and includes 77,000 kilometres of rivers, more than 25,000 wetlands, floodplain forests and lakes (Jha et al., 2012). Flooding events in this basin enable exchanges and linkages between rivers and flood plain areas to take place, which allows the ecosystem to remain healthy. Flood management within the basin is addressed at the broader catchment level and within a water resource and environmental management framework. The management framework there has always been considered to be inter- and intra-government coordination between the national and state governments and their various departments (Jha et al., 2012). The 2007 Water Act was enacted to recognize the need for legislative and policy instruments to respond to challenges due to climate change, climate variability and reduced water availability (Jha et al., 2012). Power for basin management was transferred to the newly created Murray-Darling Basin Authority. It is an independent, expert-based authority whose aim is to manage the Basin's water resources in the national interest. It is responsible for the planning and management of the Murray-Darling Basin water resources (Jha et al., 2012). Here a catchment level water resource and environmental management and is considered to be an integrated and holistic approach.

\subsection{Recommendations}

The recommendations in this section will aim to provide ways to more effectively manage water and flooding in the City of Toronto. They will be presented in four broad recommendation categories, and are based on the findings presented in the Background and Literature, Policy Context and Best Practices sections of this report. 


\subsection{Legislative Requirements}

At present, there are no legislative requirements for managing wet weather flows in the Province of Ontario. Given that policy planning in Ontario is conducted through a top-down policy framework in which the overarching legislation is established by the Provincial Government of Ontario and then implemented through provincial and municipal planning documents, it is important to first start with provincial legislation. While the Acts and PPS identified in the Policy Context section above address issues of protecting water, maintaining quality standards, setting conservation authority jurisdiction for natural heritage management, landuse planning and floodplains, and how to address and prevent natural hazards, no provincial act or legislative document guides the management of wet weather flows in Ontario. Establishing an Act with policies that relate directly to managing wet weather flows in the face of a changing climate will ensure that all municipal policies and planning documents conform to the requirements set out under the Act. This will maintain a consistent approach to managing water and flood risk across the province. It will also hold municipalities accountable for the way they manage water and will bring flood risk management within municipalities up to standard, ultimately reducing flood risk. The Flood and Water Management Act enacted in England and outlined above can be used as an example.

A provincial plan to the effect of Places to Grow or the Greenbelt Plan should be developed to guide water management in the GTA, and ensure conformity from affected municipalities. With increasing development and intensification coupled with the effects of climate change, managing water and flood risk will only continue to be more important moving into the future.

\subsection{Manage the Urban Water Cycle as a Whole}

The most important lesson learned from investigating flood impacts and adaptation measures in this report, is that the urban water cycle should be managed as a whole system with the watershed as the management unit. This involves a holistic and systems approach with integrated water 
management, giving attention to the vulnerability of drinking water and the sewerage system, to managing flood risk. The City of Toronto should be part of a larger management system that includes its watersheds. As is understood, the more agencies responsible for the management of natural systems, the greater the risk of interdepartmental conflict and time lags in implementation. Consolidation of managing authorities within the nine watersheds under the TRCAs jurisdiction will lead to a stronger management body that will be able to effectively get the job done.

The TRCA's jurisdiction (nine watersheds) should be the management unit, of which the City of Toronto is part of. An authority, whether it is a division of the TRCA or a newly created body, would be responsible for planning for both riverine and urban flood management within its jurisdiction. This body, given authority by the province, and representing the interests of all three levels of government would develop and implement a watershed plan that sets out policies to guide management in the municipalities within its jurisdiction. This body will provide the management structure and participating municipalities will be charged with implementation. Managing the watersheds as a whole, will allow for a reduction in fragmentation, jurisdictional gaps and conflicts, and will limit piecemeal and uncoordinated policies that currently exist between municipalities. This governance structure will take on a whole-system, whole-life approach to design, management and planning. It will allow for the establishment of policy that is resilient and flexible, with an acceptance that the future is uncertain, and our environment is forever being altered by human and natural forces. The Murray-Darling Basin best practice identified above can be used as an example management structure.

\subsection{Municipal Restructuring: Breaking Down the Silos}

Going forward there is a need for the integration of city planning, water management, emergency planning, and engineering, in the City of Toronto. These departments in the city already work together with the TRCA on a number of city led initiatives related to the management of water and flood risk. It is however, difficult for all these departments and an independent authority to 
cooperatively work together under separate silos in a city the size of Toronto. The importance of managing water and flood risk will only become more important in the coming years with the added impact of climate change. It is therefore important for the city to take a collaborative proactive approach to managing the problem. This has been done through the implementation of the WWFMMP, but not at a scale that includes all affected city departments and the TRCA, through the lens of the predicted future impacts of climate change. At present, there is a mismatch between the structures, process and functioning of these departments and the city's natural systems. This limits the ability of these departments to collaboratively work together and effectively respond to flood management and risk. In solving this problem the city might look to establish a body to oversee all facets of water management in the city, similar to that of Waterfront Toronto, if it is feasibly possible. Unlike Waterfront Toronto it would be under city management and would serve as a coordinating body to provide a link between the various city departments and the TRCA. This will also ensure a participatory approach by all stakeholders is taken towards water and flood management in the city. For an issue as widespread across the city as wet weather flows and flooding, a governing body within the city is warranted.

\subsection{Welcoming Water}

In establishing a holistic approach towards water management as recommended above, Toronto must change the way in which the city thinks about its river basins, waterfronts and systems. The evolution of flood management as seen in the literature has shown a move from flood control to management, and now perhaps to the thought of welcoming water. This involves a broadening of problem definitions and future solutions. It is exactly as it is stated - welcoming water - reacquainting ourselves with water and changing the way we think about it, realizing that it has and will always shape our land and the way we live. Risk acceptance with flood hazard brings forward the possibility of making room for water. This new way of understanding water will allow for a resilient rather than resistance 
approach to flooding. It seeks to reduce flood hazard risk, but accepts that there will be a residual. With increased intense rainfall storm events predicted for Toronto's future an acceptance by the city and its residents that flooding may occur now and again, will allow Toronto to seek the social and ecological pluses of flooding and aim to mitigate the minuses. It will allow for innovations in flood management and flood-receptive design. As Toronto becomes more densely populated dually functioning flood infrastructure such as Corktown Common Park in the West Donlands of Toronto, will become more important.

Welcoming water will also give opportunities for stream and river restoration. The city should actively seek opportunities for daylighting and renewal. The WWFMMP includes initiatives to strengthen streams and rivers that are already above ground, reflecting the integral role natural waterways play in maintaining the city's wet weather flow system. However, the Plan does not look at the possibility of bringing back some of Toronto's buried streams or rivers. If the city is serious about employing a hierarchy structure for managing water first at source, to divert rainwater away from the sewer system, the city must consider reviving waterways where possible. Increasing the number of surface water features such as wetlands and daylit waterways will help to remove pollutants and take pressure of storm sewers and will help to reduce flooding. Welcoming water should frame the way the city plans for and looks at managing water and flood risk moving forwards. 


\subsection{Moving Forward}

With increased human stresses on watercourses and continued sprawl of urbanization, flooding will always be a significant risk. There will always be a need to adapt current flood management policies and procedures moving into the future. The City of Toronto's approach to flooding was first shaped by the storm event Hurricane Hazel, and evolved from flood control to management. The development of the WWFMMP marked a significant step forward towards successfully managing water and wet weather flows in Toronto. While this Plan was a major achievement by the city and serves as an example to other Canadian municipalities, there is still room for improvement. Such improvements include the change to a holistic integrated approach to management, reduction in the prominence of end-of-pipe solutions, a link to climate change and resiliency, and a commitment to reporting and updating. Lack of funding is likely going to be a problem moving forwards and the city needs to come up with innovative methods to be successful in plan implementation.

The next step for Toronto in the management of its wet weather flows and watercourses is to turn to welcoming and reacquainting the city and its residents with water, as water will forever continue to shape the land and the way people live in Toronto. To effectively do this, the city will need to use a holistic integrated approach towards flood management in conjunction with climate change adaptation strategies. Managing the system as a whole on a watershed basis makes good environmental sense and will create consistency in the way water and flooding is dealt with across all municipalities in the TRCA's jurisdiction. The first step to be taken is provincial legislation to guide the way wet weather flows are to be managed across Ontario, while paying specific attention to the future impacts of climate change. From this, a watershed based management unit can plan for, and oversee the management of wet weather flows within the watersheds enabling municipalities to spearhead implementation. Managing in this way will reduce fragmentation, jurisdiction gaps and conflicts, and will limit uncoordinated policies and improve implementation. Stakeholders such as the municipal, provincial and federal governments, 
the TRCA, community representatives, and non-government organizations will need to work together to reduce risk and best manage future flooding to build a city that is more resilient to future storm events and climate change. The best practices outlined in this report provide a good stepping stone for new approaches to be taken and possible reorganization of flood management in the GTA moving forward.

It is imperative that future policies related to wet weather flows and their management have a link to climate change and building resilience. Policy that can speak to adapting to change and possible changes in the way water flows across the city's landscape will be important going forwards because no matter how extensively we plan, the future is still uncertain. 


\section{Works Cited}

Aerts, J. C., \& Botzen, W. (2011). Flood-Resilient Waterfront Development in New York City: Bridging Flood Insurance, Building Codes, and Flood Zoning. Annals of the New York Academy of Sciences , 1-82.

Authority, T. a. (2012). City of Toronto Emergency Plan. Retrieved from http://www.toronto.ca/wes/techservices/oem/pdf/flood_rsp.pdf

Blinch, M. (2013). DVP Section North of Dundas St East . Retrieved from http://phenomenonsofhistory.com/site/?p=20423

Bloch, R. (2013). Integrating Flood Risk Management and Land Use Planning. ICF International Company. Retrieved from http://resilient-cities.iclei.org/fileadmin/sites/resilientcities/files/Resilient_Cities_2013/Presentations/G3_Bloch_RC2013.pdf

Burden, A. (2011, March). Preface by the Commissioner. Vision 2020: New York City Comprehensive Waterfront Plan. New York City, New York: Department of City Planning. Retrieved from http://www.nyc.gov/html/dcp/pdf/cwp/vision2020_nyc_cwp.pdf

City of Toronto. (2003). Wet Weather Flow Management Master Plan. Toronto.

City of Toronto. (2003). Wet Weather Flow Master Plan Policy. Toronto.

City of Toronto. (2006). Wet Weather Flow Management Guidelines. Toronto.

City of Toronto. (2007). Change is in the Air: Toronto's Commitment to an Evironmentally Sustainable Future. Retrieved from http://www1.toronto.ca/City\%200f\%20Toronto/Environment\%20and\%20Energy/Our\%20Goals /Files/pdf/C/backgroundfile-2428.pdf

City of Toronto. (2008). Ahead of the Storm...Preparing Toronto for Climate Change. Retrieved from http://www1.toronto.ca/City\%200f\%20Toronto/Environment\%20and\%20Energy/Our\%20Goals /Files/pdf/A/ahead_of_the_storm.pdf

City of Toronto. (2008). Wet Weather Flow Master Plan: The Plan in Action. Toronto. Retrieved from http://www1.toronto.ca/city_of_toronto/toronto_water/files/pdf/wwfmp_5yr_implementation _report.pdf

City of Toronto. (2012). Risk Specific Plan: Flood. Retrieved from http://www.toronto.ca/wes/techservices/oem/pdf/flood_rsp.pdf

City of Toronto. (2013). Environment and Energy: Climate Change Action Plan. Retrieved from City of Toronto: http://www1.toronto.ca/wps/portal/contentonly?vgnextoid=4e4c295f69db1410VgnVCM10000 071d60f89RCRD\&vgnextfmt=default 
City of Toronto. (2014). Toronto Water 2014-2023 Capital Budget and Plan Overview. Toronto. Retrieved from

http://www1.toronto.ca/City\%200f\%20Toronto/Strategic\%20Communications/City\%20Budget/ 2014/PDFs/Analyst\%20Capital\%20Notes/Toronto\%20Water_cap_Nov22.pdf

CNN. (2011, January 17). 51 Dead from Flooding in the Philippines. CNN World. Retrieved from http://www.cnn.com/2011/WORLD/asiapcf/01/16/philippines.flooding/

Conradin, F., \& Buchli, R. (2004). The Zurich Stream Day-Lighting Program. In J. e. Marsalek (Ed.), Enhancing Urban Environment by Environmental Upgrading and Restoration (pp. 277-288). Netherlands: Kluwer Academic Publishers.

Conservation Ontario. (2003). Watershed Management in Ontario: Lessons Learned and Best Practices. Conservation Ontario. Retrieved from http://www.conservationontario.on.ca/projects/pdf/reports/PHASE\%20I/lessons_learned_best_practices.pdf

de Bruijn, K. M., Green, C., Johnson, C., \& McFadden, L. (2007). Evolving Concepts in Flood Risk Management: Searching for a Common Language. In S. B. al., Flood Risk Management in Europe (pp. 61-75). Springer.

Department of City Planning. (2011). Vision 2020: New York City Comprehensive Waterfront Plan. New York City. Retrieved from http://www.nyc.gov/html/dcp/pdf/cwp/vision2020_nyc_cwp.pdf

Edelenbos, J., van Buuren, A., \& Warner, J. (2013). Space for the River ljssel: Tortuous quests for striking an acceptable balance between water, nature and development. In Making Space for the River: Governance Experiences with Multifunctional River Flood Management in the Us and Europe (pp. 33-49). London: IWA Publishing.

Fulford, R. (1995). Accidental City: the Transformation of Toronto. Toronto: Macfarlane Walter \& Ross.

Gallopin, G. (2002). Planning for Resilience: Scenarios. In L. H. Gunderson (Ed.), Panarchy: Understanding Transformations in Human and Natural Systems (pp. 361-394). Island Press.

Godschalk, D. (2003). Urban Hazard Mitigation: Creating Resilient Cities. Natural Hazards Review, 136143. Retrieved from http://research.arch.tamu.edu/epsru/Course_Readings/Ldev671MARS689/LDEV671_Readings/ Godschalk_urbanhazardmitigation.pdf

Government of Canada. (2012). Land Use Planning Tools for Local Adaptation to Climate Change. Retrieved from http://publications.gc.ca/collections/collection_2013/rncan-nrcan/M4-1062012-eng.pdf

Gunderson, L. H., Holling, C. S., \& Light, S. S. (1995). Barriers Broken and Bridges Built: A Synthesis. In L. H. Gunderson, C. S. Holling, \& S. S. Light, Barriers and Bridges to the Renewal of Ecosystems and Institutions (pp. 489-532). New York: Columbia University Press.

Gunn, F. (2013). Woman Climbs throiugh Passenger-door Window on Lakeshore Blvd. Retrieved from http://www.winnipegfreepress.com/canada/toronto-drenched-by-flash-flooding214712781.html 
Haeuber, R. A., \& Michener, W. K. (1998). Natural Flood Control. Issues in Science and Technology, 15(1), 74-80.

Hirsh, R. M. (2011). A Perspective on Nonstationarity and Water Management. Journal of the American Water Resources Association, 47(3), 436-446.

Holling, C. S. (1986). The Resilience of Terrestrial Ecosystems: Local Surprise and Global Change. In W. C. Clark, \& R. E. Munn (Eds.), Sustainable Development of the Biosphere. Cambridge: Cambridge University Press.

Holling, C. S. (1995). What Barriers? What Bridges? In L. H. Gunderson, C. S. Holling, \& S. S. Light (Eds.), Barriers and Bridges to the Renewal of Ecosystems and Institutions (pp. 3-34). New York: Columbia University Press.

Hurricane Sandy Rebuilding Task Force. (2014). What is Rebuild by Design? Retrieved from Rebuild by Design: http://www.rebuildbydesign.org/what-is-rebuild-by-design/

Jane-Finch. (2005). Finch Flood August 19, 2005. Retrieved from http://www.janefinch.com/pictures/flood2005.htm

Kousky, C., Walls, M., \& Chu, Z. (2013). Flooding and Resilience: Valuing Conservation Investments in a World with Climate Change. Washington: Resources for the Future. Retrieved from http://www.rff.org/RFF/Documents/RFF-DP-13-38.pdf

Lintzen, H. W. (2002). Two Centuries of Central Water Management in the Netherlands. Technology and Culture, 43(3), 549-568.

Lister, N.-M. (2009). Water/Front. Places. Retrieved from http://places.designobserver.com/feature/water-front/10227/

Lorinc, J. (2013, July 12). Reduced Water Use Drains Toronto's Funds for Infrastructure Upgrades. The Globe and Mail. Retrieved from http://www.theglobeandmail.com/news/toronto/reducedwater-use-drains-torontos-funds-for-infrastructure-upgrades/article13182053/

Marsalek, J. e. (2004). City of Toronto Wet Weather Flow Management Master Plan. Enhancing Urban Environment by Environmental Upgrading and Restoration, 57-78.

Martin-Downs, D. (2013). Flood Management for the July 8th Severe Weather Event. Toronto: TRCA.

McLean, B. (2004). Paths to the Living City: The Story of Toronto and Region Conservation Authority. Toronto: Toronto and Region Conservation Authority.

Milly, P. C. (2002). Increasing Risk of Great Floods in a Changing Climate. Nature.

Ministry of Natural Resources. (2008). Ontario FLood Forecasting and Warning: Implementation Guidelines for Conservation Authorities and the Ministry of Natural Resources. Environment Canada. 
Neuman, W. (2011). Social Research Methods: Qualitative and Quantitative Approaches. Boston: Allyn \& Bacon.

Neutel, W. (2013). GO Train Stranded on Flooded Tracks Toronto. Retrieved from http://www.winnipegfreepress.com/canada/toronto-drenched-by-flash-flooding214712781.html

Richardson, A. H. (1974). Conservation by the People: The History of the Conservation Movement in Ontario to 1970. Toronto: University of Toronto Press.

Scholten, P. (2010). Leadership in Policy Innovation: a Conceptual Map. Nature and Culture, 5(1), 31-48.

The Canadian Press. (2013). Tow Truck Driver Floats Car out of DVP in Toronto July 8. Retrieved from http://blogs.windsorstar.com/2013/07/08/flooding-causes-havoc-in-toronto-with-video-andgallery/

Tippett, J., \& Griffiths, E. J. (2007). New Approaches to Flood Risk Management - Implications for Capacity-Building. In S. Ashley, S. Garvin, E. Pasche, A. Vassilopoulos, \& C. Zevenbergen (Eds.), Advances in Urban Flood Management (pp. 383-413). London: Taylor \& Francis Group.

Toronto and Region Conservation Authority. (2000). The History of Flood Control in the TRCA. Toronto: TRCA. Retrieved from http://www.trca.on.ca/dotAsset/18310.pdf

Toronto and Region Conservation Authority. (2004). The Evolution of Flood Control. Retrieved from Hurricane Hazel 50 Years Later:

http://www.hurricanehazel.ca/ssi/evolution_flood_control.shtml

Toronto Water. (2013). Stormwater Management. Retrieved from City of Toronto: http://www1.toronto.ca/wps/portal/contentonly?vgnextoid=b99807ceb6f8e310VgnVCM10000 071d60f89RCRD\&vgnextchannel=094cfe4eda8ae310VgnVCM10000071d60f89RCRD\&vgnextfmt =default

TRCA. (2013). The History of Flood Control and the Toronto and Region Conservation Authority. Retrieved from Toronto and Region Conservation: http://trca.on.ca/flood-management-service/trca-floodmanagement-program/history.dot

TRCA. (2014). Toronto \& Region Conservation Authority (TRCA): 2014 Operating Budget Overview. Retrieved from http://www.toronto.ca/legdocs/mmis/2014/ex/bgrd/backgroundfile-66010.pdf

United States Environmental Protection Agency (EPA). (2013). Wet-Weather Flow. Retrieved from USEPA: http://www.epa.gov/nrmrl/wswrd/wq/stormwater/wwf.html

Walker, B., Holling, C. S., Carpenter, S. R., \& Kinzig, A. (2004). Resilience, Adaptability and Transformability in Social Ecological Systems. Ecology and Society, 9(2), 5. Retrieved from http://www.ecologyandsociety.org/vol9/iss2/art5/print.pdf

Walters, C. J. (1986). Adaptive Management of Renewable Resources. New York: Macmillan. 
Walters et al. (2002). Resilience Management in Social-ecological Systems: A Working Hypothesis for a Participatory Approach. Ecology and Society, 6(1). Retrieved from http://www.ecologyandsociety.org/vol6/iss1/art14/

Waltner-Toews, D., Kay, J., and Lister, N.-M. (eds) (2008). The Ecosystems Approach: Complexity, Uncertainty, and Managing for Sustainability. New York: Columbia University Press.

Wang, J. (2011). Looking South onto the Toronto Don Valley Brick Works. Retrieved from http://commons.wikimedia.org/wiki/File:Toronto_Don_Valley_Brick_Works.jpg

Warner et al. . (2013). Making Space for the River: Governance Challenges. In W. e. al., Making Space for the River: Governance Experiences with Multifunctional River Flood Management in the US and Europe (pp. 1-11). London: IWA Publishing.

Warner, J., \& van Buuren, M. W. (2011). Implementing Room for the River: Narratives of Success and Failure in Kampen, The Netherlands. International Review of Administrative Sciences, 77(4), 779802.

Water Toronto. (2006). The Wet Weather Flow Master Plan Implementation: 2004-2005. City of Toronto.

Zevenbergen, C., \& Gersonius, B. (2007). Challenges in Urban Flood Management. In A. e. al., Advances in Urban Flood Management (pp. 1-12). London: Taylor \& Francis/Balkema. 